\title{
Why do investors hold socially responsible mutual funds?
}

Citation for published version (APA):

Riedl, A., \& Smeets, P. (2017). Why do investors hold socially responsible mutual funds? Journal of Finance, 72(6), 2505-2550. https://doi.org/10.1111/jofi.12547

Document status and date:

Published: 01/12/2017

DOI:

10.1111/jofi.12547

Document Version:

Publisher's PDF, also known as Version of record

Document license:

Taverne

\section{Please check the document version of this publication:}

- A submitted manuscript is the version of the article upon submission and before peer-review. There can be important differences between the submitted version and the official published version of record.

People interested in the research are advised to contact the author for the final version of the publication, or visit the DOI to the publisher's website.

- The final author version and the galley proof are versions of the publication after peer review.

- The final published version features the final layout of the paper including the volume, issue and page numbers.

Link to publication

\footnotetext{
General rights rights.

- You may freely distribute the URL identifying the publication in the public portal. please follow below link for the End User Agreement:

www.umlib.nl/taverne-license

Take down policy

If you believe that this document breaches copyright please contact us at:

repository@maastrichtuniversity.nl

providing details and we will investigate your claim.
}

Copyright and moral rights for the publications made accessible in the public portal are retained by the authors and/or other copyright owners and it is a condition of accessing publications that users recognise and abide by the legal requirements associated with these

- Users may download and print one copy of any publication from the public portal for the purpose of private study or research.

- You may not further distribute the material or use it for any profit-making activity or commercial gain

If the publication is distributed under the terms of Article $25 \mathrm{fa}$ of the Dutch Copyright Act, indicated by the "Taverne" license above, 


\title{
Why Do Investors Hold Socially Responsible Mutual Funds?
}

\author{
ARNO RIEDL and PAUL SMEETS*
}

\begin{abstract}
To understand why investors hold socially responsible mutual funds, we link administrative data to survey responses and behavior in incentivized experiments. We find that both social preferences and social signaling explain socially responsible investment (SRI) decisions. Financial motives play less of a role. Socially responsible investors in our sample expect to earn lower returns on SRI funds than on conventional funds and pay higher management fees. This suggests that investors are willing to forgo financial performance in order to invest in accordance with their social preferences.
\end{abstract}

SOCIALLY RESPONSIBLE INVESTMENTS (SRIs) are increasing in economic and financial importance, as testified by their growing volume in Europe and the United States (EUROSIF (2014), Social Investment Forum (SIF, 2014)). In the United States, for instance, already one in nine dollars of professionally managed assets are involved in SRI. These investments are a puzzle in finance, however, because they deviate from the market by excluding potentially high-return "sin" companies from their portfolio or by focusing on companies

\footnotetext{
*Arno Riedl is with CESifo, IZA, Netspar, and the Department of Economics (AE1), School of Business and Economics, Maastricht University. Paul Smeets is with the Department of Finance and European Centre for Corporate Engagement (ECCE), School of Business and Economics, Maastricht University. A former version of this paper was previously circulated under the title "Social Preferences and Portfolio Choice." We are grateful to Robeco for providing us with the administrative data used in this paper and we particularly thank Peter Jurriaans, Catrien Kleinheerenbrink, Manon Middelink, and Jorg Sunderman. This paper benefited especially from the comments and suggestions of two anonymous referees, an anonymous Associate Editor, and the Editor (Kenneth J. Singleton), as well as of Clifton Green, Chris Parsons, and Nicolas Salamanca. We are also grateful to the valuable comments of Rob Bauer, John Beshears, Thomas Dohmen, Piet Eichholtz, Uri Gneezy, Arvid Hoffmann, Christine Kaufmann, Stephan Meier, Thomas Post, Sebastien Pouget, Walid Saffar, Tao Shu, Avi Wohl, and Leonard Wolk. We thank seminar and conference participants at the EFA 2013, Society for Experimental Finance 2014 conference, Science of Philanthropy Initiative 2015, Toulouse School of Economics, UC San Diego Rady School of Management, UC San Diego Applied Microeconomics, and University of Heidelberg. We also thank Philip Abele, Oana Floroiu, John Kramer, Mohammedreza Maghroor, Tobias Ruof, Simone Vermeend, and Thorsten Voss for their help as research assistants. Paul Smeets received financial support from MISTRA and the European Centre for Corporate Engagement (ECCE). Part of this paper was written while Paul Smeets was visiting the Rady School of Management (UC San Diego). Paul Smeets is supported by a VENI grant from the Netherlands Organisation for Scientific Research (NWO) under grant number 016.Veni.175.019. The authors declare no conflict of interest.
}

DOI: $10.1111 /$ jofi.12547 
that have high scores with respect to environment, human rights, employee relations, and so forth (SIF (2014)).

Why do investors hold socially responsible mutual funds? While it is tempting to conclude that strong prosocial preferences drive this decision, other motives are also possible. On the financial side, investors may have optimistic riskreturn expectations for SRI or a desire to diversify their portfolio risk. Another possible motive could be that investors hold SRI to boost their social image or reputation.

The theoretical and empirical evidence regarding these possible explanations is inconclusive. With respect to social preferences, some theoretical models assume that investors may be willing to pay a premium to invest in socially responsible companies (e.g., Heinkel, Kraus, and Zechner (2001), Gollier and Pouget (2014)). Other recent theoretical contributions imply that holdings of SRI funds do not necessarily reflect social preferences (Dufwenberg et al. (2011), Sobel (2015)). Direct empirical evidence on the role of social preferences in SRI is missing.

A few empirical studies show that SRI equity may perform financially better (or not worse) than conventional investments. ${ }^{1}$ Other studies, however, find that investing in a socially responsible manner is financially costly. ${ }^{2}$ Thus, it is impossible to deduce from prior literature whether investors hold SRI equity funds because they expect these funds to outperform conventional equity funds; there exists little direct empirical evidence on whether investors expect SRI funds to perform better than conventional funds (Nilsson (2008), Bauer and Smeets (2015)).

Regarding reputation motives, several theoretical and experimental papers emphasize the importance of creating a positive social image via social signaling. ${ }^{3}$ Investors could achieve such a positive image, for instance, by talking to others about their SRI. As far as we know, however, no study explores social reputation as a possible motive for SRI.

In this paper, we shed light on why investors hold socially responsible mutual funds by combining administrative investor data, behavior in incentivized experiments, and survey data. Specifically, we first obtain administrative data from a large mutual fund provider that offers a wide variety of socially responsible and conventional mutual funds. Individual investors buy and sell their funds directly online without the interference of an intermediary. We then

\footnotetext{
${ }^{1}$ See, for instance, Bauer, Koedijk, and Otten (2005), Derwall et al. (2005), Kempf and Osthoff (2007), and Edmans (2011). Moreover, Karpoff, Lott, and Wehrly (2005) find that the losses of firms that violate environmental regulations are equal to the legislation costs but that firms face no additional costs due to reputation loss.

${ }^{2}$ For instance, Fabozzi, Ma, and Oliphant (2008) and Hong and Kacperczyk (2009) find that divesting from sin industries that involve weapons, tobacco, alcohol, or gambling is costly because these companies tend to perform better than "nonsin" companies. Moreover, Krüger (2015) finds that stock prices sometimes react negatively to positive corporate social responsibility (CSR) news.

${ }^{3}$ Theoretical contributions include Glazer and Konrad (1996), Bénabou and Tirole (2006), and Ellingsen and Johannesson (2008). Empirical evidence is provided by Ariely, Bracha, and Meier (2009), Fehrler and Przepiorka (2013), and Cappelen et al. (2017).
} 
merge these data with results from a survey and incentivized experiments that we conducted using a large group of individual investors. We thus create a unique data set that links the administrative data of conventional and socially responsible investors to their behavior in controlled experiments and to answers in a comprehensive survey.

To investigate the potential effects of social preferences on portfolio choice, it is necessary to have a clean and independent measure of such preferences. This measure should ideally be unaffected by strategic reputation considerations (Kreps et al. (1982)) or social image concerns (Ellingsen and Johannesson (2008)). To obtain such a measure, we let investors participate in a controlled and anonymous one-shot trust game experiment (Berg, Dickhaut, and McCabe (1995)). The trust game is a two-player sequential move game where the first mover can transfer money to the second mover. The transferred amount is tripled by the experimenter. The second mover can send back to the first mover all, parts, or none of the money received. The behavior of the first mover mainly captures trust, which is why the game is called a trust game. However, we want to capture social preferences rather than trust. We therefore use the behavior of investors in the role of second movers to measure intrinsic social preferences (Karlan (2005), Falk, Meier, and Zehnder (2013)). A second mover who behaves like the prototypical homo economicus should not send back any money. The more an investor in the role of second mover returns, the stronger are the investor's intrinsic social preferences.

We find that intrinsic social preferences play an important role in determining SRI. An investor who equally shares the money in the experiment is 14 percentage points more likely to hold an SRI equity fund compared to a selfish investor who keeps all the money. This effect is economically substantial as only $16 \%$ of our total sample holds an SRI equity fund. We also find that social signaling motivates investors' SRI equity holdings; investors who talk more often about their investments are more likely to invest in a socially responsible way. Moreover, socially responsible investors donate about $41 \%$ more to charity than conventional investors, implying that SRI is not a substitute for charity donations.

Financial motives also play a role in whether investors hold SRI. On the one hand, we find that investors are willing to pay significantly higher management fees on SRI funds than on conventional funds and a majority of investors expect SRI funds to underperform relative to conventional funds. On the other hand, we find that investors who expect SRI equity funds to underperform relative to conventional equity funds are less likely to invest in a socially responsible manner. Hence, our evidence indicates that some investors are willing to forgo financial performance in order to invest in mutual funds that are in concordance with their social preferences, but at the margin pessimistic performance expectations reduce the likelihood of investing in a socially responsible way. Investors who expect SRI equity funds to perform financially better than conventional equity funds are not more likely to hold such funds.

Risk perceptions are unrelated to holdings of SRI funds. However, investors who generally hold funds longer are more likely to invest in SRI equity funds, 
which indicates that socially responsible investors have a longer investment horizon. We also find that investors with larger portfolios are more likely to hold SRI, perhaps for risk diversification reasons. ${ }^{4}$ Individual socioeconomic characteristics only play a marginal role in determining whether investors hold SRI equity funds.

Overall, we identify a number of factors that influence individuals' decisions to invest in a socially responsible manner. Our most robust and strongest result is that intrinsic social preferences play a dominant role, even when controlling for risk preferences, trading activity, realized Sharpe ratios, and other investor characteristics.

Interestingly, when we look only at investors who hold an SRI equity fund in their portfolio, we do not find a significant relation between social preferences and the percentage invested in SRI equity funds. This suggests that strong social preferences are needed to buy an SRI fund in the first place, but that they are less important for choosing the fraction of the portfolio to allocate to SRI funds once this first hurdle has been overcome. However, in line with the social signaling hypothesis, we find that investors with weak social preferences who strongly signal their investment behavior hold significantly smaller shares in SRI. This suggests that relatively selfish investors who hold SRI for signaling reasons minimize the percentage of SRI they hold. In addition, we find that financial motives affect the fraction invested in SRI funds. In particular, investors with a larger portfolio invest a smaller fraction in SRI funds, most likely to diversify their portfolio.

Our empirical results are related to several theoretical models. In their seminal work, Heinkel, Kraus, and Zechner (2001) develop a model in which some investors refrain from investing in nonresponsible companies. These investors drive up the price and lower the expected returns of socially responsible companies, because the risk of nonresponsible firms is borne by fewer investors. Similarly, Fama and French (2007) show that taste for assets can influence stock prices. Gollier and Pouget (2014) develop a model in which investors can improve the social responsibility of firms by excluding nonresponsible companies from their portfolio or by activism against nonresponsible firms. ${ }^{5}$ Our paper provides empirical support for a key assumption of these models: social preferences are indeed an important determinant of investment decisions.

Some previous empirical studies show that socially responsible investors may behave differently from conventional investors. Bollen (2007) and Renneboog, Ter Horst, and Zhang (2011) find that, ex post, investors are more likely to hold on to badly performing SRI funds than to poorly performing conventional funds. Hong and Kostovetsky (2012) report that, in comparison to Republican fund

\footnotetext{
${ }^{4}$ An anonymous referee pointed out that wealthy investors might hold SRI for social capital reasons. We cannot exclude this possibility as our data do not lend themselves to investigating this hypothesis.

${ }^{5}$ De Bettignies and Robinson (2015) develop a model that examines whether CSR is beneficial for society. Baron (2007) models socially responsible firm behavior as donations. He shows that the cost of social responsibility is borne by the social entrepreneur when going public rather than by the shareholder as long as CSR is anticipated by shareholders.
} 
managers, Democratic fund managers select stocks that score higher on social responsibility. ${ }^{6}$ Importantly, these studies do not distinguish between whether socially responsible investors hold different beliefs regarding the performance of SRI funds, are motivated by social reputation concerns, or are motivated by intrinsic social preferences. Another important difference with Hong and Kostovetsky is that investors in our study make decisions for their own account instead of on behalf of others. This difference is important, as Andersson et al. (2013) show that decisions made for others can differ vastly from decisions made for oneself.

Understanding investors' reasons for holding SRI funds is important because, as Fama and French (2007) show, taste for assets can have long-run effects on asset prices, whereas differences in beliefs have only short-run effects (e.g., Bénabou and Tirole (2010), Borgers et al. (2013)). We find little evidence for the beliefs hypothesis. Rather, social preferences and-to some extent-social signaling are important for SRI decisions. The effect of social preferences is likely to be particularly long lasting, as SRI has been steadily rising in recent years. As SRI continues to grow, ${ }^{7}$ socially responsible investors might have even more of an effect on asset prices by driving up prices of socially responsible companies and driving down prices of sin companies.

The remainder of the paper is organized as follows. Section I introduces the data, Section II describes the variables, and Section III discusses individualand portfolio-level investor characteristics. Section IV presents our main analysis of investors' motives for holding SRI equity funds. Section V examines investor characteristics related to their social preferences and social signaling, and Section VI explores the relationship between SRI and charitable donations. Section VII concludes, discusses questions left open by our study, and suggests some avenues for future research on SRI.

\section{Data}

In this section, we first describe the administrative investor data. Next we give a description of the survey data. Finally, we provide details on the incentivized experiments.

\section{A. Administrative Investor Data}

We use administrative individual investor data from one of the largest mutual fund providers in the Netherlands. The data cover the period June 2006 to

\footnotetext{
${ }^{6}$ Di Giuli and Kostovetsky (2014) also demonstrate that companies run by a Democratic-leaning CEO are more likely to go green than firms run by a Republican-leaning CEO. Other papers investigating SRI decisions include Statman (2004), Nilsson (2008), Hood, Nofsinger, and Varma (2014), and Bauer and Smeets (2015).

${ }^{7}$ Previous studies show that mutual funds that advertise observe larger inflows of money into these funds (e.g., Jain and Wu (2000), Cronqvist (2006)). The growing interest in SRI could make it more attractive for mutual funds to advertise these funds in the near future, further increasing the market share of SRI.
} 
June 2012. The mutual fund provider offers a wide range of investment funds, including equity funds, bond funds, and mixed funds. Within these categories, funds can be global, sector-specific, SRI, and more. ${ }^{8}$ The administrative data for each investor contain all monthly fund holdings, including SRI funds. ${ }^{9} \mathrm{We}$ define as socially responsible investors that hold at least one SRI equity fund in their portfolio.

\section{B. Survey Data}

The survey and experiments were conducted in June 2011. The administrative data provide information on 3,382 socially responsible investors, all of whom were invited to participate in the survey. In addition to the socially responsible investors, we randomly selected 35,000 investors of the approximately 145,000 remaining accounts in the database. ${ }^{10}$ We sent an email containing a link to the online survey to all selected investors. The response rate was $8 \%$ for conventional investors and $12 \%$ for socially responsible investors. We deliberately invited disproportionately more socially responsible investors to increase statistical power when comparing them to conventional investors. Relative to the invited sample, respondents are slightly more likely to be male and older, and to hold larger portfolios (see Table A.1 in the Appendix for a comparison of the survey respondents and the overall sample regarding gender, age, total portfolio value, and the percentage of SRI equity holdings). We control for these and other demographic variables in our analyses.

In the online survey, investors answered questions and took part in experiments with monetary incentives (see below for details). At the beginning of the survey, respondents received some general information and were informed that they would take part in several experiments, but they were not informed about the content of the experiments until the experiments actually took place. The introduction to the survey also explained the general procedure regarding possible monetary earnings in the experiments. In the first part of the survey, we asked general investment questions such as assets held, the number of

\footnotetext{
${ }^{8}$ Figure IA1 in the Internet Appendix, available in the online version of the article on the Journal of Finance website, shows a screenshot of the product selector of the mutual fund provider. The product selector shows for each fund the category to which it belongs and whether the provider classifies the fund as sustainable, emerging market, global, etc. On the same screen, investors can read details about the fund, including stock selections based on social responsibility criteria. In addition, the product selector gives information such as past performance, Morningstar ratings, and fees.

${ }^{9}$ Our survey (see below) indicates that $83 \%$ of all investors (including those who do not hold SRI funds) respond positively or neutrally to the statement that SRI have a positive influence on society. Only $26 \%$ of respondents indicate in another statement that they believe SRI funds are a marketing trick to sell more funds. We are therefore confident that funds defined as SRI funds are perceived as such by most investors.

${ }^{10}$ We excluded investors who no longer held the account at the time we conducted the survey. We also did not invite investors who never placed a single trade or who were younger than 18 .
} 
investment accounts, and investment goals. In this part investors also participated in an experiment designed to elicit risk preferences. More questions on investment behavior then followed. Toward the middle of the survey, investors participated in an experiment eliciting their intrinsic social preferences. We asked all survey questions regarding SRI and other behavior that could be interpreted as related to social goals after the experiments concluded.

Survey questions have some known limitations. For instance, respondents might differ from nonrespondents and respondents' answers may depend upon how the questions are framed. We discuss a potential response bias in our results below and conclude that if a response bias is present, it likely weakens the effects we identify and we thus err on the conservative side. Regarding framing effects, it is important to note that all investors received the same questions. Because we are primarily interested in potential differences in beliefs and attitudes between socially responsible and conventional investors, any framing effects should be similar for these groups. Surveys also have major benefits. Specifically important for our purposes, a survey allows us to gather information about return expectations on and risk perceptions of SRI in comparison to conventional equity investments, information that would otherwise remain unobserved. Moreover, we can collect information on other important control variables like self-rated investment knowledge, income level, education, etc. See Guiso, Sapienza, and Zingales (2013) for further discussion of the pros and cons of surveys for studying financial decisions.

\section{Incentivized Experiments ${ }^{11}$}

Investors participated in a risk preferences elicitation experiment as well as in an interactive experiment with other investors where we elicited their social preferences. All experiments were incentivized with real money. Investors were informed that their earnings depended on their own decisions and (in some cases) on the decisions of other investors. They were also informed that whether they would receive the earnings from the experiment would be determined randomly (with a chance of 1 in 10 ) at the end of the survey. ${ }^{12}$ Those who were selected for payment got one of the experiments paid out at random. Investors received their earnings via bank transfer the first working day after they completed the survey, and the payments were guaranteed by the authors' university. We used a unique identification number to link the choices in the experiments and survey answers to our administrative data. To ensure anonymity of investors, we hired an external company that specializes in conducting online research to handle the payments. This company does not have access to the trading records or other information of the investors. Survey participants were informed about this at the beginning of the survey.

\footnotetext{
11 The experiment instructions can be found in Section I in the Internet Appendix.

${ }^{12}$ For a recent validation of this procedure, see Dohmen et al. (2011).
} 


\section{C.1. Risk Preferences}

We elicited risk preferences using incentivized multiple price list lotteries, similar to Dohmen et al. (2011) (see also Holt and Laury (2002)). Investors faced 20 decision situations in which they had to choose between a specific sure amount and a lottery with a 50\% chance of winning 300 euro and a $50 \%$ chance of not winning anything. The sure amount was minimally 0 euro and maximally 190 euro and increased in steps of 10 euro from one decision situation to the next. The choice options presented are reported in Table A.2 in the Appendix. Participants made decisions in all 20 decision situations. For incentive compatibility reasons, and in accordance with the literature on risk elicitation experiments, only one of these 20 situations was randomly selected to be paid out.

The decision situation in which participants switch between the lottery and the certain outcome informs us about their risk preferences. We therefore use this switching point as a measure of an individual's risk attitude. As the sure amount is ordered from low to high, a higher switching point from the lottery to the sure amount indicates a greater degree of risk tolerance.

\section{C.2. Social Preferences}

To measure intrinsic social preferences, we use a variant of the trust game experiment introduced by Berg, Dickhaut, and McCabe (1995). The trust game is a two-player sequential game. Both the first mover and the second mover are endowed with 50 euro. ${ }^{13}$ The first mover decides on the amount to send to the second mover, which can be any multiple of 5 euro, including 0 and 50 . The amount sent is tripled by the experimenter and the second mover decides how much of the money received to return to the first mover. Hence, the earnings of the first mover are 50 euro minus the amount sent plus the amount returned by the second mover. The earnings of the second mover are 50 euro plus triple the amount sent by the first mover minus the money sent back. ${ }^{14}$

We use second mover behavior to measure intrinsic social preferences. ${ }^{15}$ To obtain a comprehensive measure of intrinsic social preferences as well as for practical implementation reasons, we employ the so-called strategy method (Selten (1967)), whereby each second mover decides how much to send back for each of the 10 possible nonzero amounts sent by the first mover (ranging

\footnotetext{
${ }^{13}$ Since its introduction by Berg, Dickhaut, and McCabe (1995), it is standard practice in the literature using trust game experiments to endow both participants with the same initial amount (e.g., Fehr and List (2004), Falk, Meier, and Zehnder (2013), Falk and Zehnder (2013)). The main reason is to avoid experimenter-induced unequal positions ex ante.

14 The money sent by the first mover and tripling of this amount by the experimenters is "free lunch" for the second mover. One may argue that second movers could act differently if they needed to earn these benefits. Unfortunately, there is no evidence available on how second mover behavior in trust games would change if first mover transfers and tripling of the transfer were not free. We therefore adopt the standard procedure.

${ }^{15}$ We also have data on the behavior of first movers in the trust game, but we do not report them here for brevity and because these data intermingle trust and social preferences (Cox (2004)).
} 
from 5 euro to 50 euro) before knowing the actual amount sent. Specifically, the experiment instructions inform second movers that "[f] or technical reasons you should make your decision without knowing how much money the person to whom you have been linked has actually sent you. Therefore, for each possible amount that the other person could send you, we would like to ask you to indicate how much you would like to return. However, only the decision that is relevant for the amount that has actually been sent is decisive for your income and the income of the person to whom you have been linked."

In addition to generating a comprehensive measure of intrinsic social preferences, another important advantage of the strategy method is that it simulates sequential moves for each possible choice of the first mover without deceiving subjects and without requiring that players' choices indeed be sequential over time. Similar versions of the strategy method have been successfully used in recent trust game experiments (see, for example, Baran, Sapienza, and Zingales (2010), Falk, Meier, and Zehnder (2013), and Falk and Zehnder (2013)).

Each investor was either a first mover or a second mover. Every work day, we randomly matched first movers to second movers. After choices were made, we implemented the one choice out of the 10 possible choices of the second mover that corresponded to the actual choice of the first mover, if the first mover made a nonzero transfer. For example, if the first mover transferred 30 euro to the second mover, we used the amount that the second mover wanted to return for that transfer to calculate earnings. In the example, the second mover would receive $3 \times 30=90$ euro from the first mover. If the second mover decided to return, say, 45 euro, the earnings of the second mover would be $90-45+50$ (endowment) $=95$ euro and the earnings of the first mover would be $-30+45+50$ (endowment) $=65$ euro. If the choice of the first mover was to send zero, both movers earned their initial endowment of 50 euro.

Second movers in the trust game are randomly assigned to one of two conditions. Under one condition, they are matched to a first mover who is a randomly chosen investor participating in the survey and the experiment. Under the other condition, a second mover is randomly matched to a first mover who is a socially responsible investor participating in the survey and the experiment. We inform subjects in the introduction to the experiment about the condition to which they belong without telling them that there are two different conditions. ${ }^{16}$ Investors received experiment instructions online and had to answer a couple of comprehension questions about the rules of the game and how the payment is calculated before the experiment started. These questions were correctly answered by $89.5 \%$ of the investors. ${ }^{17}$

\footnotetext{
${ }^{16}$ We do not find differences in behavior between conditions and therefore use the pooled data in our analysis below.

${ }^{17}$ We conduct our main analysis using all investors. In robustness analyses reported in the Appendix, we confirm that the results remain qualitatively unchanged when excluding investors who answered at least one question incorrectly after three trials (see Table A.6).
} 
The trust game was played only once. The investors were informed about this and also about the fact that they and the other participants in the experiment would remain anonymous during and after the experiment. The fact that the trust game is played only once rules out repeated-game effects. Moreover, the fact that second movers know that their behavior will never be revealed to anybody and is known only anonymously to the experimenters, minimizes prosocial behavior in the trust game that is due to reputation and social image effects. We are therefore confident that we can interpret second mover behavior as a clean measure of intrinsic social preferences. In Section II.C.2, we discuss how we quantify this measure in more detail.

Before we move on, we comment on the stake sizes used in the experiment, as they may seem small relative to investors' assets and incomes. We are confident that the stake sizes do not jeopardize our results for the following reasons. First, as the most important effect of no or low stakes is an increase in the amount of noise in the data (Camerer and Hogarth (1999)), too low stakes would likely reduce our ability to detect a relation between social preferences identified in our experiment and SRIs in the field. Therefore, if anything, the stake sizes we employ are likely to err on the conservative side. Second, the payoffs in our experiment can be considered reasonable given the time investors actually spent on the experiment. On average it took participants 45 minutes to complete the survey and all experiments. Therefore, the potential payment probably was not too far off from participants' opportunity costs, especially when considering that investors likely participated in their leisure time. Third, although quantitatively moderate stake size effects have been reported in experiments similar to ours, qualitatively these effects do not differ much across low and high stakes (Oosterbeek, Sloof, and Van De Kuilen (2004)). ${ }^{18}$

\section{Variables}

All variables discussed here are summarized in Table A.3 in the Appendix. Table A.4 in the Appendix reports summary statistics for all variables and results of statistical tests comparing socially responsible and conventional investors. Below we discuss in turn the variables from (A) the administrative transaction data, (B) the survey questions, and (C) the experiments.

\section{A. Administrative Variables}

\section{A.1. SRI Equity Fund Holdings}

As mentioned above, we classify investors as socially responsible if they own at least one SRI equity fund at the time of the experiment. We construct Percentage in SRI equity funds, as the average amount invested in SRI equity funds in the year after the experiment as a percentage of the total amount invested in equity funds over the same period.

\footnotetext{
${ }^{18}$ For a discussion of stake size effects, see also Falk and Heckman (2009).
} 


\section{A.2. Other Portfolio Characteristics}

We construct Log total portfolio value as the logarithm of the average euro amount invested in bonds and equity at the provider in the year before the survey and experiment, and Log number of transactions as the logarithm of the number of trades an investor made in the 12 months prior to the experiment. The variable Average holding period specifies the average number of months an investor has held a mutual fund over the period June 2006 to June 2011.

We calculate Mean portfolio returns as the average portfolio return in the year before the investor participated in the survey and experiment and Volatility portfolio returns as the monthly portfolio volatility over the same period. The Sharpe ratio is equal to Mean portfolio returns divided by Volatility portfolio returns in the year before the experiment.

\section{B. Survey Variables}

\section{B.1. Return Expectations and Risk Perceptions}

To explore the importance of financial motives, we elicit return expectations and risk perceptions regarding SRI equity funds compared to conventional equity funds. To capture investors' expected returns, we use responses to the statement "I expect that the returns of socially responsible equity funds compared to conventional equity funds are: Much lower, A bit lower, The same, A bit higher, Much higher, I do not know." Only 2.5\% of the socially responsible investors and $10.2 \%$ of the conventional investors chose "I do not know." For our regression models, to be introduced below, we create two dummy variables from these responses. The dummy variable Lower expected returns on SRI takes a value of one if the investor expects returns on SRI funds to be much lower or a bit lower than returns on conventional equity funds and zero otherwise. The dummy variable Higher expected returns on SRI takes a value of one if the investor expects much higher or a bit higher returns on SRI funds compared to conventional equity funds and zero otherwise. Equal return expectations form the base category.

To measure risk perceptions of SRI equity funds compared to conventional equity funds, we asked investors to rate their agreement with the statement "Socially responsible equity funds are more risky than conventional equity funds." Responses to these statements had to be rated on a 7-point Likert scale, from 1 "Disagree completely" to 7 "Agree completely." We create the two dummy variables from these responses. The variable Lower perceived risk on SRI takes a value of one if the investor perceives the risk of SRI equity funds to be lower than that of conventional equity funds (Likert scale 1 to 3 ) and zero otherwise, while the dummy variable Higher perceived risk on $S R I$ takes a value of one if the investor perceives the risk of SRI equity funds to be higher than the risk of conventional equity funds (Likert scale 5 to 7 ) and zero otherwise. Equally perceived risk perceptions (Likert scale 4) form the base category. 


\section{B.2. Signaling}

Investors buy and sell funds at the mutual fund provider directly online without the interference of an intermediary. Therefore, in principle, nobody observes an investor's portfolio. As a result, investors who want to signal to others that they invest in SRI funds have to talk about their investments with others. To capture the extent to which investors may use SRI funds to signal prosocial investment activity, we asked investors for their agreement with the statement "I often talk about investments with others," again on a 7-point Likert scale ranging from "fully disagree" (Likert scale 1) to "fully agree" (Likert scale 7). The question is phrased in neutral terms to avoid experimenter demand effects as well as socially desirable responses. The answers to the statement are coded by the variable Signaling. The variable Strong signaling is a dummy variable that takes on the value of one for investors who score greater than or equal to the median value of Signaling and zero otherwise.

\section{B.3. Investment Knowledge, SRI Perception, Education Level, and Other Investor Characteristics}

Similar to other studies (Dorn and Huberman (2005), Graham, Harvey, and Huang (2009), Van Rooij, Lusardi, and Alessie (2011)), we measure selfassessed Investment knowledge with the statement "My investment knowledge is good." Investors rated their agreement on a 7-point Likert scale from 1 "Fully disagree" to 7 "Fully agree."

We also elicited investors' perception of the social impact of SRI by asking them to report their agreement with the statement "SRI funds have a positive influence on society" ( 1 = "Fully disagree" to $7=$ "Fully agree"). The dummy variable Perceived social impact is equal to one for investors who gave an answer greater than or equal to the median answer and zero otherwise.

We also asked for investors' highest-achieved education level. The dummy variable University degree is equal to one if the investor indicated having a university degree and zero otherwise.

Finally, we gathered information on investors' gender, age, and income. The dummy variable Female takes the value of one if the investor is a woman and zero if the investor is a man. The variable Age is measured in years and reflects an investor's self-reported age in years. Investors also self-reported their annual gross family income. We construct the dummy variables Low income (below 60,000 euro), Median income (between 60,000 euro and 100,000 euro), and High income (above 100,000 euro) such that each category comprises about one-third of the sample. The variable Untold income is equal to one for investors who were unwilling to report their income and zero otherwise.

\section{B.4. Donations}

Charitable donations could substitute for or complement SRI. To test for such a relation we asked investors how much they donate to charity each 
year on average. The variable Log donations specifies the logarithm of this average.

\section{Experiment Variables}

\section{C.1. Risk Preferences}

The variable Risk preferences indicates the sure money amount at which the investor switches from choosing the risky lottery to the risk-free option in the risk preference elicitation experiment. A higher amount indicates greater risk tolerance.

\section{C.2. Intrinsic Social Preferences}

We use second-mover behavior in our one-shot anonymous trust game experiment to elicit intrinsic social preferences. Through the use of the strategy method, we have 10 monetary return decisions for each investor in the role of second mover. To capture intrinsic social preferences, we aggregate these return decisions and construct the natural measure "mean intrinsic social preferences." Specifically, for each possible nonzero first-mover transfer (i.e., 5 euro, 10 euro, . . , 50 euro), we calculate the ratio of the back-transfer and take the average. In the remainder of the paper, we refer to this measure as Intrinsic social preferences or just Social preferences, for brevity.

\section{Individual and Portfolio Characteristics of Socially Responsible and Conventional Investors}

Table I shows that $16.2 \%$ of the investors in the sample can be classified as socially responsible investors, that is, as investors who hold at least one SRI equity fund. These investors hold on average 4,574 euro in SRI equity funds, which corresponds to $23.0 \%$ of their total equity investments. Socially responsible investors invest overwhelmingly in SRI equity funds (94.2\%), as compared to SRI bond funds (5.8\%).

Regarding individual characteristics, we find that in comparison to conventional investors socially responsible investors are more likely to hold a university degree $\left(59.0 \%\right.$ versus $46.7 \% ; \boldsymbol{X}^{2}$ test $\left.{ }^{19} p=0.009\right)$, rate their investment knowledge higher (4.3 versus 4.1 ; $t$-test, $p=0.029$ ), and are marginally less likely to be female $\left(12.3 \%\right.$ versus $18.7 \% ; \boldsymbol{X}^{2}$ test, $\left.p=0.064\right)$. With respect to portfolio characteristics, the only substantial difference between the two sets of investors is that socially responsible investors hold larger portfolios than conventional investors (Log total portfolio value: 10.7 versus 10.3 ; $t$-test, $p=$ $0.002) .^{20}$

\footnotetext{
${ }^{19}$ All tests are two-sided.

20 The interested reader can find the full set of comparisons of individual and portfolio characteristics in Table A.4 in the Appendix.
} 
Table I

\section{Portfolios of Socially Responsible Investors}

This table provides details on the fund holdings of conventional investors and socially responsible investors, that is, investors who hold SRI equity funds. Total portfolio value refers to investors' total portfolio value across SRI and conventional investments. Amount invested in SRI equity is the average amount investors hold in SRI equity. \% of equity invested in SRI equity is the amount invested in SRI equity divided by the total amount invested in equity. \% of SRI investments in SRI equity is the fraction of all socially responsible funds invested in SRI equity funds rather than SRI bond funds.

\begin{tabular}{lccccc}
\hline & $\begin{array}{c}\text { \% of } \\
\text { Investors }\end{array}$ & $\begin{array}{c}\text { Total Portfolio } \\
\text { Value }(€)\end{array}$ & $\begin{array}{c}\text { Amount } \\
\text { Invested in SRI } \\
\text { Equity }(€)\end{array}$ & $\begin{array}{c}\% \text { of Equity } \\
\text { Invested in } \\
\text { SRI Equity }\end{array}$ & $\begin{array}{c}\text { Investments } \\
\text { in SRI } \\
\text { Equity }\end{array}$ \\
\hline $\begin{array}{c}\text { Conventional } \\
\text { investors }\end{array}$ & $83.8 \%$ & 70,235 & - & - & - \\
$\begin{array}{c}\text { Socially responsible } \\
\text { investors }\end{array}$ & $16.2 \%$ & 104,332 & 4,574 & $23.0 \%$ & $94.2 \%$ \\
\begin{tabular}{l} 
Overall \\
\hline
\end{tabular} & $100 \%$ & 75,778 & - & - & - \\
\hline
\end{tabular}

\section{Why Do Investors Hold SRI Equity Funds?}

Our primary objective is to shed light on the role of financial and social motives in holding SRI funds. To do so, we begin in Section IV.A by comparing the realized portfolio performance of socially responsible and conventional investors. Next in Section IV.B, we examine investors' expectations regarding the return and risk of SRI funds. In Section IV.C, we use regression analysis to explore the role of financial as well as social motives, controlling for a battery of individual background variables. In regard to social motives, we distinguish between intrinsic social preferences, which refer to prosocial motives that do not provide any future (material) benefit to the individual itself, and social signaling, which refers to motives to show others that one invests in a responsible manner because doing so improves one's own social reputation. ${ }^{21}$

\section{A. Portfolio Performance}

Panel A of Table II reports the realized performance of the equity part of socially responsible investors' (column (1)) and conventional investors' (column (2)) portfolios over the one, three, and five years prior to the survey and experiment. Note that the reported returns correspond to the returns that individual investors realized on the funds they selected in their portfolio, and not to the funds' aggregate performance.

\footnotetext{
${ }^{21}$ Several theories in finance and economics introduce social preferences in their models (e.g., Andreoni (1990), Rabin (1993), Fehr and Schmidt (1999), Bolton and Ockenfels (2000), Heinkel, Kraus, and Zechner (2001), Charness and Rabin (2002), Sobel (2005), and Gollier and Pouget (2014)). For contributions on signaling theory, see Glazer and Konrad (1996), Bénabou and Tirole (2006), and Ellingsen and Johannesson (2008).
} 


\section{Table II}

\section{Investment Performance of Socially Responsible and Conventional Investors}

Panel A presents the realized portfolio performance of the equity part of sample investors' portfolios, with results reported separately for socially responsible investors and conventional investors. Panel B is limited to socially responsible investors and compares the performance of the "SRI equity" and the "Non-SRI equity" parts of their portfolio. Panel C reports the average yearly total expense ratio (TER) of SRI equity funds and conventional equity funds. $p$-values refer to two-sided $t$-tests.

\begin{tabular}{|c|c|c|c|}
\hline \multicolumn{4}{|c|}{ Panel A. All Investors } \\
\hline & $\begin{array}{l}\text { Socially Responsible } \\
\text { Investors }\end{array}$ & $\begin{array}{l}\text { Conventional } \\
\text { Investors }\end{array}$ & $p$-Value \\
\hline \multicolumn{4}{|c|}{ 1-year portfolio performance } \\
\hline Mean return & $7.45 \%$ & $7.02 \%$ & 0.0678 \\
\hline Volatility & $16.05 \%$ & $15.29 \%$ & 0.3494 \\
\hline Sharpe ratio & 0.95 & 1.15 & 0.0414 \\
\hline \multicolumn{4}{|c|}{ Average 3-year portfolio performance } \\
\hline Mean return & $0.16 \%$ & $0.63 \%$ & 0.0206 \\
\hline Volatility & $23.51 \%$ & $22.79 \%$ & 0.2757 \\
\hline Sharpe ratio & 0.01 & 0.06 & 0.1781 \\
\hline \multicolumn{4}{|c|}{ Average 5-year portfolio performance } \\
\hline Mean return & $-1.29 \%$ & $-1.18 \%$ & 0.5003 \\
\hline Volatility & $20.19 \%$ & $19.69 \%$ & 0.3394 \\
\hline Sharpe ratio & -0.07 & -0.06 & 0.4811 \\
\hline
\end{tabular}

Panel B. Socially Responsible Investors

\begin{tabular}{lccr}
\hline & SRI Equity & Non-SRI Equity & $p$-Value \\
\hline 1-year portfolio performance & & & \\
Mean return & $2.71 \%$ & $7.88 \%$ & 0.0000 \\
Volatility & $30.60 \%$ & $14.00 \%$ & 0.0000 \\
Sharpe ratio & 0.45 & 1.07 & 0.0000 \\
Average 3-year portfolio performance & & & \\
Mean return & $-0.82 \%$ & $0.53 \%$ & 0.0000 \\
Volatility & $30.76 \%$ & $22.57 \%$ & 0.0000 \\
Sharpe ratio & -0.02 & 0.04 & 0.0019 \\
Average 5-year portfolio performance & & & \\
Mean return & $-4.06 \%$ & $-0.98 \%$ & 0.0000 \\
Volatility & $17.46 \%$ & $18.72 \%$ & 0.2568 \\
Sharpe ratio & -0.19 & -0.06 & 0.0000 \\
\hline
\end{tabular}

Panel C. Administrative Cost Ratios

\begin{tabular}{lccr}
\hline & SRI Equity Funds & \multicolumn{2}{c}{ Conventional Equity Funds } \\
\hline Average yearly expense ratio (TER) & $2.20 \%$ & $1.50 \%$ & 0.0230 \\
\hline
\end{tabular}

The results show that, overall, the equity performance of socially responsible is similar to that of conventional investors. In the one year before the experiment, socially responsible investors realized marginally significantly higher Mean returns on their equity investments than conventional investors but 


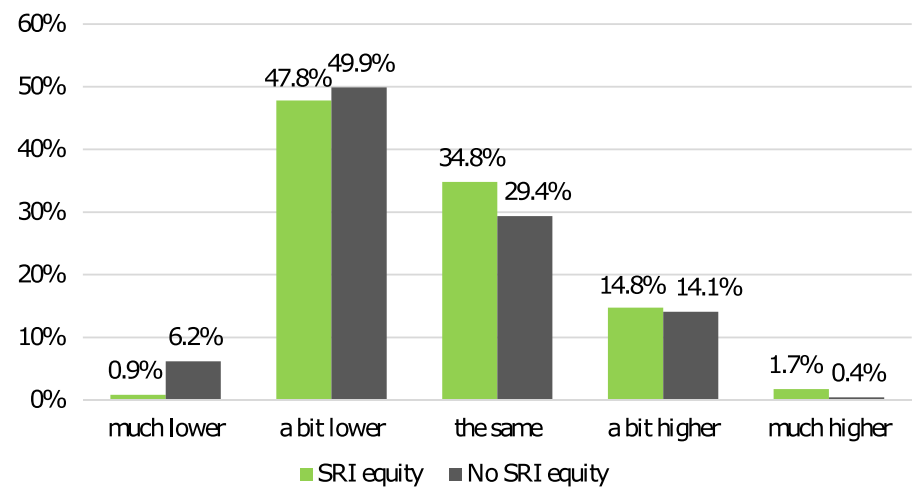

Figure 1. Return expectations of SRI equity funds. This figure provides the distribution of return expectations of SRI equity funds separately for investors with and without an SRI equity fund ("SRI equity" and "No SRI equity," respectively). The bars depict investor responses to the statement "I expect that the returns of socially responsible equity funds compared to conventional equity funds are: $1=$ much lower, $2=$ a bit lower, $3=$ the same, $4=$ a bit higher, $5=$ much higher." The category "I don't know" is excluded from the figure; it was chosen by $2.5 \%$ of socially responsible investors and $10.2 \%$ of conventional investors. (Color figure can be viewed at wileyonlinelibrary.com)

significantly worse Sharpe ratios ( $p=0.0414)$. Over the three years before the experiment, socially responsible investors realized significantly lower Mean returns than conventional investors $(p=0.0206)$ but did not differ in terms of the Sharpe ratio. No difference exists in the performance of socially responsible and conventional investors for the five years preceding the experiment.

Panel B limits attention to socially responsible investors and compares the performance of the "SRI equity" part of their portfolio to the performance of the "non-SRI equity" part. The results show that socially responsible investors realized significantly lower Mean returns and worse Sharpe ratios on the SRI equity part of their portfolio over all three horizons considered $(p<$ 0.002 ).

Finally, Panel $\mathrm{C}$ of the table shows that the average yearly total expense ratio (TER) is significantly higher for socially responsible equity funds than for conventional equity funds $(2.2 \%$ versus $1.5 \%, p=0.023)$. These extra fees are used to screen portfolios on environmental and social criteria.

Taken together the above results indicate that financial motives are unlikely to be the main driver behind SRI. However, investors' subjective performance expectations regarding SRI funds could be biased and if the bias is sufficiently large investors may still invest in SRI funds for purely financial reasons. We explore this possibility next.

\section{B. Expected Returns and Risk Perceptions about SRI Funds}

Figure 1 displays the distribution of expected returns on SRI equity funds compared to conventional equity funds for socially responsible and conventional investors (see also Table A.4 in the Appendix). The figure shows that both 


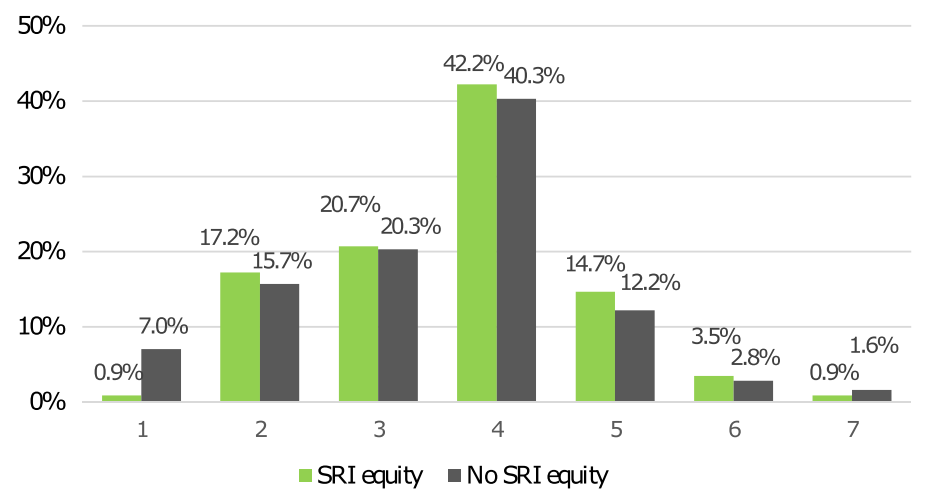

Figure 2. Risk perceptions of SRI equity funds. This figure provides the distribution of risk perceptions of SRI funds separately for investors with and without an SRI equity fund ("SRI equity" and "No SRI equity," respectively). The bars depict investor responses on a 7-point Likert scale to the statement "Socially responsible equity funds are more risky than conventional equity funds," where 1 corresponds to "Fully disagree" and 7 to "Fully agree." (Color figure can be viewed at wileyonlinelibrary.com)

investor types are relatively pessimistic regarding the performance of SRI funds, with only $16.5 \%$ and $14.5 \%$ of socially responsible and conventional investors, respectively, expecting higher returns on SRI than on conventional funds. Socially responsible investors are slightly less pessimistic about the returns of SRI funds than are conventional investors. For instance, $48.7 \%$ of socially responsible investors and $56.1 \%$ of conventional investors expect to earn much or a bit lower returns on SRI than on conventional funds. The difference between socially responsible and conventional investors is marginally significant (Kolmogorov-Smirnov test, $p=0.054$ ).

Figure 2 shows the distribution of the perceived risk on SRI equity funds relative to conventional equity funds for socially responsible and conventional investors. Socially responsible and conventional investors appear to have similar risk perceptions regarding SRI equity funds. The difference in the distributions of risk perceptions between socially responsible and conventional investors is not significant (Kolmogorov-Smirnov test, $p=0.186$ ).

Taken together, the results on return expectations and risk perceptions show that socially responsible investors have a slightly more positive view of the performance of SRI equity funds than conventional investors. Although the differences are small, performance expectations could still play some role in explaining why investors hold SRI funds. Another financial motive to hold SRI funds could be risk diversification. Although investors might perceive the risk of an SRI fund in isolation to be equally risky as a conventional equity fund, they might hold an SRI fund to diversify their portfolio. The survey data show that this motive is virtually absent. Only $5.4 \%$ of all socially responsible investors indicate that they hold SRI funds to pursue diversification benefits. 


\section{Regression Results: Social and Financial Motives of Socially Responsible Investors}

Table III studies simultaneously investors' different possible motives for holding socially responsible mutual funds. The first specification presents marginal effects of a probit regression in which the dependent variable is a dummy that takes the value of one if an investor holds an SRI equity fund and zero otherwise. In our specification, we control for several variables related to investors' portfolios, namely, Average holding period, Log total portfolio value, and Log number of transactions. We also control for several individual-level characteristics, in particular, Investment knowledge, University degree, Risk preferences, Female, and Age, as well as Low income, High income, and Untold income, where medium income is the omitted reference category for the income measures. Below we discuss results for social motives, financial motives, and the other characteristics in turn.

As we noted before, in investigating the role of social motives, we distinguish between intrinsic social preferences and signaling. The results for specification (1) show that stronger intrinsic social preferences have a highly significant positive effect on the likelihood of investing in a socially responsible manner $(p=0.003)$. For example, an investor who equally splits earnings in the trust game with the first mover is $2 * 0.0694=14$ percentage points more likely to hold an SRI fund than a completely selfish investor who returns zero to the first mover. This effect is economically substantial given that $16 \%$ of investors in our sample hold SRI equity funds. Signaling is also significantly positively related to the likelihood of investing in SRI equity funds. An investor who scores one point higher on the signaling variable is 2.3 percentage points more likely to invest in an SRI equity fund ( $p=0.035)$.

Specification (1) further shows that Lower expected returns on SRI is negative and marginally statistically significant $(p=0.071)$. Specifically, an investor who expects SRI equity funds to underperform relative to conventional equity funds is 5.8 percentage points less likely to hold an SRI equity fund. However, investors who expect SRI equity funds to perform better than conventional equity funds are not significantly more likely to hold such a fund $(p=0.239)$. This suggests that investors do not hold SRI equity funds because they expect these funds to financially outperform conventional funds, but rather that investors who are pessimistic about the performance of SRI funds avoid such funds. The risk perception dummies are not significant, which indicates that investors do not hold SRI equity funds because they perceive their risk to be lower. These results suggest that the perceived performance of SRI equity funds does play some role in SRI decisions, but also that financial motives alone do not explain the decision to invest in SRI funds.

Specification (1) of Table III also shows that investors who hold funds longer (Average holding period) are more likely to invest in SRI equity funds. This finding indicates that socially responsible investors have a longer investment horizon. Investors who hold their funds one year longer are $0.0023 * 12=2.76$ percentage points more likely to hold an SRI equity fund. 


\section{Table III}

\section{Why Do Investors Hold Socially Responsible Equity Funds?}

Specification (1) presents marginal effects of a probit regression. The dependent variable is $S R I$ equity, which takes the value of one if an investor holds an SRI equity fund in the month investors participated in the experiment and survey and zero otherwise. Specification (2) presents coefficients of an OLS regression. The dependent variable is \% in SRI equity funds, which is equal to the investor's holdings in SRI equity funds as a share of his or her total investments in equity. In specification (2) only investors who hold at least one SRI equity fund are considered. Social preferences: ratio of money that second movers in the trust game send back; Signaling: the extent to which an investor agrees with the statement "I often talk about investment with others"; Sharpe ratio: the Sharpe ratio of the investor's portfolio performance; Lower expected returns on $S R I$ : dummy variable equal to one if the investor believes that the returns on SRI equity funds are a bit or much lower than on conventional equity funds; Higher expected returns on SRI: dummy variable equal to one if the investor believes that the returns on SRI equity funds are a bit or much higher than on conventional equity funds; Lower perceived risk on SRI: dummy variable equal to one if the investor disagrees with the statement that the risk of SRI equity funds is higher than the risk of conventional equity funds; Higher perceived risk on SRI: dummy variable equal to one if the investor agrees with the statement that the risk of SRI equity funds is higher than the risk of conventional equity funds; Average holding period: average number of months the investor has held a mutual fund in the five years before the survey and experiment; Log total portfolio value: logarithm of the investor's average euro amount invested at the provider; Log number of transactions: logarithm of the number of transactions the investor made in the year before the survey and experiment; Investment knowledge: the extent to which the investor agrees with the statement "My investment knowledge is good"; University degree: dummy variable equal to one if the investor reports having a university degree; Risk preferences: experimental measure of investor's risk tolerance; Female: dummy variable equal to one if investor reports being a woman; Age: the investor's age; Low Income: dummy variable equal to one if the investor's reported annual gross family income is below 60,000 euro; High Income: dummy variable equal to one if the investor's reported annual gross family income is above 100,000 euro; Untold income: dummy variable equal to one if the investor does not disclose income. For definitions of the variables, see also Table A.3. Robust standard errors are reported in parentheses. *,**, and *** indicate significance at the $10 \%$, $5 \%$, and $1 \%$ level, respectively.

$\begin{array}{cc}\text { Probit } & \text { OLS } \\ \text { Has SRI Equity } & \% \text { in SRI Equity } \\ (1) & (2)\end{array}$

\section{Social motives}

Social preferences

$\begin{array}{cc}0.0694 * * * & -0.0204 \\ (0.0233) & (0.0479) \\ 0.0228 * * & -0.0181 \\ (0.0108) & (0.0169)\end{array}$

Signaling

$(0.0108)$

Financial motives

Sharpe ratio

$(0.0205)$

(0.0537)

Lower expected returns on SRI

$-0.0581^{*}$

$-0.0730$

(0.0322)

$(0.0492)$

Higher expected returns on SRI

$-0.0433$

$-0.0358$

(0.0368)

$(0.0677)$

Lower perceived risk on SRI

$-0.0422$

$-0.0141$

(0.0302)

(0.0503)

Higher perceived risk on SRI

0.0065

0.0639

(0.0441)

(0.0720) 
Table III-Continued

\begin{tabular}{|c|c|c|}
\hline & $\begin{array}{c}\text { Probit } \\
\text { Has SRI Equity } \\
\text { (1) }\end{array}$ & $\begin{array}{c}\text { OLS } \\
\% \text { in SRI Equity } \\
(2)\end{array}$ \\
\hline \multicolumn{3}{|l|}{ Portfolio characteristics } \\
\hline Average holding period & $\begin{array}{l}0.0023 * * \\
(0.0010)\end{array}$ & $\begin{array}{r}-0.0015 \\
(0.0019)\end{array}$ \\
\hline Log total portfolio value & $\begin{array}{l}0.0390 * * * \\
(0.0126)\end{array}$ & $\begin{array}{c}-0.0572 * * * \\
(0.0197)\end{array}$ \\
\hline Log number of transactions & $\begin{array}{l}0.0252^{* *} \\
(0.0114)\end{array}$ & $\begin{array}{c}0.0162 \\
(0.0266)\end{array}$ \\
\hline \multicolumn{3}{|l|}{ Individual characteristics } \\
\hline Investment knowledge & $\begin{array}{c}0.0022 \\
(0.0119)\end{array}$ & $\begin{array}{r}-0.0315^{*} \\
(0.0188)\end{array}$ \\
\hline University degree & $\begin{array}{c}0.0553^{*} \\
(0.0314)\end{array}$ & $\begin{array}{c}0.0505 \\
(0.0547)\end{array}$ \\
\hline Risk preferences & $\begin{array}{c}-0.0001 \\
(0.0004)\end{array}$ & $\begin{array}{l}0.0015^{* *} \\
(0.0006)\end{array}$ \\
\hline Female & $\begin{array}{c}0.0074 \\
(0.0424)\end{array}$ & $\begin{array}{c}-0.0241 \\
(0.0584)\end{array}$ \\
\hline Age & $\begin{array}{c}-0.0025^{*} \\
(0.0014)\end{array}$ & $\begin{array}{c}0.0009 \\
(0.0022)\end{array}$ \\
\hline Low income & $\begin{array}{c}0.0243 \\
(0.0387)\end{array}$ & $\begin{array}{c}0.0196 \\
(0.0608)\end{array}$ \\
\hline High income & $\begin{array}{c}-0.0255 \\
(0.0383)\end{array}$ & $\begin{array}{c}0.0176 \\
(0.0645)\end{array}$ \\
\hline Untold income & $\begin{array}{c}-0.0062 \\
(0.0417)\end{array}$ & $\begin{array}{c}-0.0121 \\
(0.0666)\end{array}$ \\
\hline Constant & & $\begin{array}{l}0.8089 * * * \\
(0.2892)\end{array}$ \\
\hline Observations & 625 & 121 \\
\hline$R^{2}$ & & 0.1820 \\
\hline
\end{tabular}

The value of the portfolio (Log total portfolio value) is positively related to the likelihood of investing in SRI. For instance, a doubling of the portfolio size is associated with a 3.9 percentage point increase in the likelihood of investing in a socially responsible manner $(p=0.002)$. This relatively strong effect is intuitive as investors with larger portfolios likely spread their greater wealth over various funds, including SRI funds. We also see a slightly positive and significant effect of the number of transactions (Log number of transactions), which indicates that more active investors are more likely to invest in SRI funds.

Of the individual-level characteristics, only University degree and Age exhibit statistically (marginally) significant effects: having a university degree tends to increase the likelihood of holding SRI funds whereas being older decreases it.

Specification (2) presents results of an ordinary least squares (OLS) regression for investors who hold at least one SRI fund. We find that, conditional on holding an SRI equity fund, neither social preferences nor signaling explain the 
percentage invested in SRI equity funds. These results suggest that, while social motives are key for investing in a socially responsible manner at all, they do not influence the percentage invested in SRI once this hurdle has been cleared. Rather, financial motives appear to determine the percentage invested in SRI funds. Investors with a larger portfolio invest a significantly smaller fraction of their portfolio in SRI funds $(p=0.004)$. This result is consistent with the interpretation that these investors diversify their portfolio over non-SRI funds more than investors with smaller portfolios.

Of the individual characteristics considered, only Investment knowledge and Risk preferences exhibit (marginally) significant effects on the share of SRI held. Better investment knowledge has a marginally significant negative effect, whereas higher risk tolerance has a significant positive effect.

In Table IV, we explore the role of social preferences and social signaling in more detail using dummy variables. In specifications (1) and (3), we present marginal effects from a probit regression in which the dependent variable is a dummy that takes the value of one if an investor holds an SRI equity fund and zero otherwise. In specifications (2) and (4), we present coefficients of an OLS regression where the dependent variable is the percentage invested in SRI equity funds for those investors who hold an SRI equity fund. The variable Strong social preferences takes the value of one if an investor shares the money in the experiment at least equally and zero otherwise. The variable Strong signaling takes the value of one if an investor scores greater than or equal to the median for signaling and zero otherwise.

The results in specification (1) show that the relation between social preferences and the likelihood of holding an SRI fund that we find above is robust to this nonlinear specification of the social preference variable. Investors who give away at least half of their money in the experiment are significantly more likely to invest in SRI funds than more selfish investors $(p=0.033)$. Consistent with the linear specification for social preferences reported in Table III, strong social preferences explain the likelihood of investing in SRI funds but not the percentage invested in SRI funds conditional on holding an SRI fund (specification (2)). This again indicates that social preferences are important for the decision of whether to buy an SRI fund, but less important for the decision of what fraction of all equity investments to allocate to SRI equity funds.

Consistent with the results of the linear specification for signaling, the variable Strong signaling is not significant for explaining either the choice to hold an SRI fund or the percentage held in SRI funds. However, signaling may matter most for investors with weak social preferences, because these investors are likely to hold SRI funds only if doing so benefits their reputation. We test this hypothesis in specifications (3) and (4).

To do so, we decompose the full set of investors into subgroups according to the strength of their social preferences and the strength of their social signaling. The first subgroup consists of investors with strong social preferences, 


\section{Table IV}

\section{The Effect of Strong and Weak Social Preferences and Signaling}

Specifications (1) and (3) present marginal effects of probit regressions. The dependent variable is SRI equity, which takes the value of one if an investor holds an SRI equity fund in the month investors participated in the experiment and survey and zero otherwise. Specifications (2) and (4) present coefficients of OLS regressions. The dependent variable is \% in SRI equity funds, which is equal to the investor's holdings in SRI equity funds as a share of his or her total investments in equity. In specifications (2) and (4) only investors who hold at least one SRI equity fund are considered. Strong social preferences: dummy variable equal to one if the investor's average return ratio in the trust game is such that it gives the other player at least half of the money in the experiment; Strong signaling: dummy variable equal to one if the investor's signaling strength is greater than or equal to the median level of signaling; Weak social preferences \& strong signaling: dummy variable equal to one if both the investor's average return ratio in the trust game is such that it gives the other player less than half of the money in the experiment and the investor exhibits strong signaling. For definitions of the other variables, see Table III and Table A.3. Robust standard errors are reported in parentheses. *, **, and *** indicate significance at the 10\%, 5\%, and $1 \%$ level, respectively.

\begin{tabular}{|c|c|c|c|c|}
\hline & $\begin{array}{c}\text { Probit } \\
\text { Has SRI Equity } \\
\text { (1) }\end{array}$ & $\begin{array}{c}\text { OLS } \\
\% \text { in SRI Equity } \\
(2)\end{array}$ & $\begin{array}{c}\text { Probit } \\
\text { Has SRI Equity } \\
\text { (3) }\end{array}$ & $\begin{array}{c}\text { OLS } \\
\% \text { in SRI Equity }\end{array}$ \\
\hline \multicolumn{5}{|l|}{ Social motives } \\
\hline Strong social preferences & $\begin{array}{l}0.0644^{* *} \\
(0.0313)\end{array}$ & $\begin{array}{c}-0.0138 \\
(0.0485)\end{array}$ & $\begin{array}{l}0.1084^{* *} \\
(0.0441)\end{array}$ & $\begin{array}{r}-0.1155 \\
(0.0812)\end{array}$ \\
\hline Strong signaling & $\begin{array}{c}0.0386 \\
(0.0317)\end{array}$ & $\begin{array}{c}-0.0684 \\
(0.0511)\end{array}$ & & \\
\hline $\begin{array}{l}\text { Weak social preferences } \\
\text { \& strong signaling }\end{array}$ & & & $\begin{array}{c}0.0686 \\
(0.0435)\end{array}$ & $\begin{array}{c}-0.1604^{* *} \\
(0.0780)\end{array}$ \\
\hline \multicolumn{5}{|l|}{ Financial motives } \\
\hline Sharpe ratio & $\begin{array}{c}0.0037 \\
(0.0211)\end{array}$ & $\begin{array}{c}0.0510 \\
(0.0519)\end{array}$ & $\begin{array}{c}0.0041 \\
(0.0212)\end{array}$ & $\begin{array}{c}0.0494 \\
(0.0552)\end{array}$ \\
\hline $\begin{array}{l}\text { Lower expected returns } \\
\text { on SRI }\end{array}$ & $\begin{array}{r}-0.0561^{*} \\
(0.0325)\end{array}$ & $\begin{array}{r}-0.0700 \\
(0.0475)\end{array}$ & $\begin{array}{r}-0.0557^{*} \\
(0.0324)\end{array}$ & $\begin{array}{r}-0.0702 \\
(0.0459)\end{array}$ \\
\hline $\begin{array}{l}\text { Higher expected returns } \\
\text { on SRI }\end{array}$ & $\begin{array}{r}-0.0441 \\
(0.0372)\end{array}$ & $\begin{array}{r}-0.0369 \\
(0.0670)\end{array}$ & $\begin{array}{r}-0.0432 \\
(0.0371)\end{array}$ & $\begin{array}{r}-0.0369 \\
(0.0651)\end{array}$ \\
\hline $\begin{array}{l}\text { Lower perceived risk on } \\
\text { SRI }\end{array}$ & $\begin{array}{r}-0.0375 \\
(0.0303)\end{array}$ & $\begin{array}{r}-0.0194 \\
(0.0514)\end{array}$ & $\begin{array}{r}-0.0371 \\
(0.0303)\end{array}$ & $\begin{array}{r}-0.0218 \\
(0.0499)\end{array}$ \\
\hline $\begin{array}{l}\text { Higher perceived risk on } \\
\text { SRI }\end{array}$ & $\begin{array}{c}0.0028 \\
(0.0441)\end{array}$ & $\begin{array}{c}0.0606 \\
(0.0696)\end{array}$ & $\begin{array}{c}0.0042 \\
(0.0443)\end{array}$ & $\begin{array}{c}0.0586 \\
(0.0654)\end{array}$ \\
\hline \multicolumn{5}{|l|}{ Portfolio characteristics } \\
\hline Average holding period & $\begin{array}{l}0.0022 * * \\
(0.0010)\end{array}$ & $\begin{array}{r}-0.0016 \\
(0.0019)\end{array}$ & $\begin{array}{l}0.0023^{* *} \\
(0.0010)\end{array}$ & $\begin{array}{c}-0.0021 \\
(0.0019)\end{array}$ \\
\hline Log total portfolio value & $\begin{array}{l}0.0375^{* * *} \\
(0.0127)\end{array}$ & $\begin{array}{c}-0.0590 * * * \\
(0.0199)\end{array}$ & $\begin{array}{l}0.0371 * * * \\
(0.0127)\end{array}$ & $\begin{array}{c}-0.0566^{* * * *} \\
(0.0191)\end{array}$ \\
\hline $\begin{array}{l}\text { Log number of } \\
\text { transactions }\end{array}$ & $\begin{array}{l}0.0255^{* *} \\
(0.0113)\end{array}$ & $\begin{array}{c}0.0150 \\
(0.0257)\end{array}$ & $\begin{array}{l}0.0256^{* *} \\
(0.0112)\end{array}$ & $\begin{array}{c}0.0088 \\
(0.0250)\end{array}$ \\
\hline Individual characteristics & & & & \\
\hline Investment knowledge & $\begin{array}{c}0.0068 \\
(0.0117)\end{array}$ & $\begin{array}{c}-0.0339 * \\
(0.0186)\end{array}$ & $\begin{array}{c}0.0063 \\
(0.0114)\end{array}$ & $\begin{array}{c}-0.0340 * \\
(0.0181)\end{array}$ \\
\hline University degree & $\begin{array}{c}0.0503 \\
(0.0316)\end{array}$ & $\begin{array}{c}0.0576 \\
(0.0544)\end{array}$ & $\begin{array}{c}0.0504 \\
(0.0316)\end{array}$ & $\begin{array}{c}0.0456 \\
(0.0539)\end{array}$ \\
\hline
\end{tabular}


Table IV-Continued

\begin{tabular}{|c|c|c|c|c|}
\hline & $\begin{array}{c}\text { Probit } \\
\text { Has SRI Equity } \\
\text { (1) }\end{array}$ & $\begin{array}{c}\text { OLS } \\
\% \text { in SRI Equity } \\
(2)\end{array}$ & $\begin{array}{c}\text { Probit } \\
\text { Has SRI Equity } \\
\text { (3) }\end{array}$ & $\begin{array}{c}\text { OLS } \\
\% \text { in SRI Equity }\end{array}$ \\
\hline Risk preferences & $\begin{array}{c}-0.0001 \\
(0.0004)\end{array}$ & $\begin{array}{l}0.0015^{* * *} \\
(0.0006)\end{array}$ & $\begin{array}{c}-0.0001 \\
(0.0004)\end{array}$ & $\begin{array}{l}0.0013 * * \\
(0.0006)\end{array}$ \\
\hline Female & $\begin{array}{c}0.0024 \\
(0.0419)\end{array}$ & $\begin{array}{c}-0.0234 \\
(0.0587)\end{array}$ & $\begin{array}{c}-0.0014 \\
(0.0410)\end{array}$ & $\begin{array}{c}-0.0261 \\
(0.0538)\end{array}$ \\
\hline Age & $\begin{array}{c}-0.0026^{*} \\
(0.0014)\end{array}$ & $\begin{array}{c}0.0009 \\
(0.0023)\end{array}$ & $\begin{array}{c}-0.0027^{*} \\
(0.0014)\end{array}$ & $\begin{array}{c}0.0008 \\
(0.0023)\end{array}$ \\
\hline Low income & $\begin{array}{c}0.0230 \\
(0.0390)\end{array}$ & $\begin{array}{c}0.0177 \\
(0.0609)\end{array}$ & $\begin{array}{c}0.0224 \\
(0.0389)\end{array}$ & $\begin{array}{c}0.0125 \\
(0.0599)\end{array}$ \\
\hline High income & $\begin{array}{c}-0.0275 \\
(0.0385)\end{array}$ & $\begin{array}{c}0.0278 \\
(0.0655)\end{array}$ & $\begin{array}{c}-0.0285 \\
(0.0382)\end{array}$ & $\begin{array}{c}0.0239 \\
(0.0642)\end{array}$ \\
\hline Untold income & $\begin{array}{c}-0.0090 \\
(0.0416)\end{array}$ & $\begin{array}{c}-0.0075 \\
(0.0678)\end{array}$ & $\begin{array}{r}-0.0088 \\
(0.0413)\end{array}$ & $\begin{array}{c}-0.0040 \\
(0.0632)\end{array}$ \\
\hline Constant & & $\begin{array}{l}0.8047^{* * * *} \\
(0.2549)\end{array}$ & & $\begin{array}{l}0.9032^{* * * *} \\
(0.2599)\end{array}$ \\
\hline $\begin{array}{l}\text { Observations } \\
R^{2}\end{array}$ & 625 & $\begin{array}{c}121 \\
0.1887\end{array}$ & 625 & $\begin{array}{c}121 \\
0.2211\end{array}$ \\
\hline
\end{tabular}

irrespective of their strength of signaling. ${ }^{22}$ As above, these investors are captured by the dummy variable Strong social preferences. Investors with weak social preferences are further divided into a subgroup with strong signaling and a subgroup with weak signaling. The investors with both weak social preferences and strong signaling are captured by the dummy variable Weak social preferences \& strong signaling, which takes the value of one if both the investor gives the other player less than half of the money in the experiment and scores at or above the median for signaling, and zero otherwise. The remaining investors, that is, those with weak social preferences and weak signaling, form the base group. The coefficients on the dummy variables Strong social preferences and Weak social preferences \& strong signaling should therefore be interpreted relative to this base group.

The results, reported in specification (3) of Table IV, suggest that investors with both weak social preferences and strong signaling are more likely to invest in SRI funds than investors with both weak social preferences and weak signaling, but the statistical significance is not strong $(p=0.103)$. The results confirm that investors with strong social preferences are significantly more likely to invest in SRI funds $(p=0.009)$.

Importantly, specification (4) of Table IV shows that investors who hold SRI funds and have both weak social preferences and strong signaling invest a

\footnotetext{
${ }^{22}$ For investors with strong social preferences, we do not distinguish between weak and strong signaling because we find that the relation between strong social preferences and holding SRI is almost identical for strong and weak signaling (see Table IAVII in the Internet Appendix). We therefore merge these subgroups into the group Strong social preferences to increase statistical power.
} 
significantly smaller fraction of their portfolio in SRI funds $(p=0.042)$. This result is consistent with the hypothesis that selfish investors who are strongly motivated by social reputation concerns are investing a rather small fraction in SRI funds when they invest in SRI. The smaller fraction in SRI funds allows these investors to signal that they invest in SRI funds while keeping the potential financial disadvantages of holding SRI to a minimum. The effects of all other variables that we considered are similar to those reported in Table III.

Next, we examine whether beliefs about the social impact of SRI drive investment in SRI and whether our results reported so far are robust to controlling for such beliefs. Table $\mathrm{V}$ reports on regression analysis, in which we explore whether investors who hold more positive views about the social impact of SRI funds are also more likely to hold such funds. Column (1) shows that this is indeed the case $(p=0.016)$. However, consistent with our result for social preferences, investors who hold a positive view of the social impact of SRI do not hold a larger fraction of their portfolio in SRI funds (column (2), $p=$ 0.987). Similar to specifications (3) and (4) of Table IV, in specifications (3) and (4) of Table V we use the variables Strong social preferences and Weak social preferences \& strong signaling. Importantly, the results show that the previously documented effects of social preferences and signaling are robust to the inclusion of the perceived social impact variable. The effects of all other variables considered are similar to those reported for the original specification (see Table IV).

In addition to the analyses above, we have also conducted a number of additional regressions to check the robustness of the relation between social motives and SRI. The results of these tests are reported in Tables A.5 to A.8 in the Appendix and Table IAVI in the Internet Appendix. The regressions reported in Table A.5 exclude all investors who believe that SRI are a marketing trick (10.6\% of the sample). Table A.6 excludes all investors who incorrectly answered at least one question from the comprehension questions of the experiment (11.3\% of the sample). Table A.7 excludes all investors who expect higher returns on SRI and perceive lower risk on SRI but still do not invest in these funds (6.5\% of the sample). Table A.8 includes the full set of signaling dummies. Finally, Table IAVI also includes investors who held an SRI equity fund at least once over the period between 2006 and the time the survey was taken. The results reported in these tables show that our main results regarding the effects of social motives on SRI are robust to these variations.

\section{Characteristics Related to Intrinsic Social Preferences and Social Signaling}

We next investigate which investor characteristics are related to social preferences and social signaling. Table VI reports the results of OLS regressions with Social preferences (specification (1)) or Signaling (specifications (2) and (3)) as the dependent variable and portfolio characteristics as well as individual characteristics as explanatory variables. Specification (1) shows that, for social preferences, only the coefficient of Risk preferences is marginally 


\section{Table V}

\section{Perceived Social Impact of SRI}

Specifications (1) and (3) present marginal effects of probit regressions. The dependent variable is SRI equity, which takes the value of one if an investor holds an SRI equity fund in the month investors participated in the experiment and survey and zero otherwise. Specifications (2) and (4) present coefficients of OLS regressions. The dependent variable is \% in SRI equity funds, which is equal to the investor's holdings in SRI equity funds as a share of the total investments in equity. In specifications (2) and (4) only investors who hold at least one SRI equity fund are considered. Perceived social impact: dummy variable equal to one if the investor's agreement with the statement "Socially responsible investment funds have a positive influence on society" is greater than or equal to the median level of agreement. For definitions of the other variables, see Tables III, IV, and A.3. Robust standard errors are reported in parentheses. * **, and *** indicate significance at the $10 \%$, $5 \%$, and $1 \%$ level, respectively.

\begin{tabular}{cccc}
\hline Probit & OLS & Probit & OLS \\
Has SRI Equity & $\%$ in SRI Equity & Has SRI Equity & \% in SRI Equity
\end{tabular}

(1)

Social motives

Perceived social impact

Strong social preferences

$\begin{array}{lr}0.0470^{* *} & -0.0005 \\ (0.0194) & (0.0275)\end{array}$

Weak social preferences \& strong signaling

Financial motives

Sharpe Ratio

Lower expected returns on SRI

Higher expected returns on SRI

Lower perceived risk on SRI

Higher perceived risk on SRI

Portfolio characteristics

Average holding period

Log total portfolio value

Log number of transactions

Individual characteristics

Investment knowledge

University degree

Risk preferences

Female

(0.0069)

$-0.0146$

(0.0121)
(2)

(3)
(4)

0.0191

(0.0497)

$-0.1167$

(0.0810)

$-0.1620^{* *}$

(0.0781)

0.0493

(0.0547)

$-0.0682$

(0.0457)

$-0.0380$

(0.0650)

$-0.0264$

(0.0534)

0.0526

(0.0707)

$(0.0421)$

$-0.0020$

(0.0019)

(0.0010)

$0.0373 * * *$

(0.0128)

$0.0265^{* *}$

$-0.0564 * *$

(0.0190)

0.0093

(0.0249)

(0.0111)

$-0.0340^{*}$

(0.0183)

0.0460

(0.0540)

$0.0014 * *$

(0.0006)

$-0.0273$

(0.0544) 
Table V-Continued

\begin{tabular}{lcccc}
\hline & $\begin{array}{c}\text { Probit } \\
\text { Has SRI Equity } \\
(1)\end{array}$ & $\begin{array}{c}\text { OLS } \\
\text { in SRI Equity } \\
(2)\end{array}$ & $\begin{array}{c}\text { Probit } \\
\text { Has SRI Equity } \\
(3)\end{array}$ & $\begin{array}{c}\text { OLS } \\
\text { in SRI Equity } \\
(4)\end{array}$ \\
\hline Age & $-0.0037^{* * * *}$ & -0.0019 & $-0.0029^{* *}$ & 0.0006 \\
& $(0.0009)$ & $(0.0013)$ & $(0.0014)$ & $(0.0024)$ \\
Low income & 0.0231 & 0.0107 & 0.0280 & 0.0157 \\
& $(0.0228)$ & $(0.0353)$ & $(0.0390)$ & $(0.0638)$ \\
High income & -0.0090 & 0.0230 & -0.0226 & 0.0276 \\
& $(0.0234)$ & $(0.0339)$ & $(0.0387)$ & $(0.0675)$ \\
Untold income & -0.0201 & -0.0354 & 0.0037 & 0.0019 \\
& $(0.0253)$ & $(0.0325)$ & $(0.0430)$ & $(0.0687)$ \\
Constant & & $1.1609^{* * *}$ & & $0.8796 * * *$ \\
& & $(0.1849)$ & & $0.2705)$ \\
Observations & 1,803 & 346 & 625 & 121 \\
$R^{2}$ & & 0.2186 & & 0.2223 \\
\hline
\end{tabular}

significant, and small. Interestingly, male and female investors are equally prosocial in the experiment, and there is no difference between young and old investors.

Specification (2) looks at the determinants of social signaling and shows that Investment knowledge is positively related to signaling $(p<0.001)$ and that women (Female) and older investors (Age) signal less about investments than men and younger investors ( $p<0.001$ and $p=0.046$, respectively). In addition, investors with a University degree care less about signaling than less educated investors.

These results show that intrinsic social preferences are not confined to investors with specific demographic or portfolio-related characteristics. None of the characteristics above are good proxies for such preferences, which implies that it is important to measure such preferences independently. Social signaling, in contrast, is stronger for young male investors with good investment knowledge. These results indicate that the two types of social motivations for investing in a socially responsible manner correspond to different types of investors.

Specification (3) shows that Strong social preferences are significantly negatively related to signaling $(p<0.001)$. This finding is consistent with the interpretation that, for investors with a strong intrinsic motivation, it is less important to signal their prosocial behavior to others than it is for investors whose intrinsic motivation is weak. This result is also consistent with the effect documented in Table IV that investors with weak social preferences but a strong signaling motive who hold SRI funds hold a relatively small fraction of such funds. ${ }^{23}$

\footnotetext{
${ }^{23}$ In line with existing research on gender in finance, we find that self-reported investment knowledge is lower for women than for men (average rating on 7-point Likert scale: men $=4.03$, women $=3.29 ; p<0.001$, two-sided $t$-test). To check the robustness of our regression results in
} 


\section{Table VI}

\section{Covariates of Intrinsic Social Preferences and Social Signaling}

Specification (1) reports coefficients of an OLS regression with Social preferences as the dependent variable. Specifications (2) and (3) report OLS regressions in which the dependent variable is Signaling. For definitions of the variables, see Tables III and A.3. Robust standard errors are reported in parentheses. *, **, and *** indicate significance at the $10 \%, 5 \%$, and $1 \%$ level, respectively.

\begin{tabular}{|c|c|c|c|}
\hline & $\begin{array}{c}\text { Social Preferences } \\
\text { (1) }\end{array}$ & $\begin{array}{l}\text { Signaling } \\
\quad(2)\end{array}$ & $\begin{array}{l}\text { Signaling } \\
(3)\end{array}$ \\
\hline Strong social preferences & & & $\begin{array}{c}-0.3907 * * * \\
(0.1037)\end{array}$ \\
\hline \multicolumn{4}{|l|}{ Portfolio characteristics } \\
\hline Average holding period & $\begin{array}{c}0.0001 \\
(0.0019)\end{array}$ & $\begin{array}{c}-0.0020 \\
(0.0024)\end{array}$ & $\begin{array}{c}-0.0034 \\
(0.0037)\end{array}$ \\
\hline Log total portfolio value & $\begin{array}{c}-0.0045 \\
(0.0218)\end{array}$ & $\begin{array}{c}-0.0356 \\
(0.0244)\end{array}$ & $\begin{array}{c}-0.0229 \\
(0.0399)\end{array}$ \\
\hline Log number of transactions & $\begin{array}{r}-0.0076 \\
(0.0227)\end{array}$ & $\begin{array}{c}0.0103 \\
(0.0248)\end{array}$ & $\begin{array}{r}-0.0482 \\
(0.0437)\end{array}$ \\
\hline \multicolumn{4}{|l|}{ Individual characteristics } \\
\hline Investment knowledge & $\begin{array}{r}-0.0061 \\
(0.0213)\end{array}$ & $\begin{array}{l}0.4712^{* * *} \\
(0.0228)\end{array}$ & $\begin{array}{l}0.4956^{* * * *} \\
(0.0378)\end{array}$ \\
\hline University degree & $\begin{array}{c}-0.0125 \\
(0.0543)\end{array}$ & $\begin{array}{c}-0.1367^{* *} \\
(0.0616)\end{array}$ & $\begin{array}{c}-0.0129 \\
(0.1045)\end{array}$ \\
\hline Risk preferences & $\begin{array}{c}0.0012^{*} \\
(0.0007)\end{array}$ & $\begin{array}{c}-0.0011 \\
(0.0008)\end{array}$ & $\begin{array}{c}0.0002 \\
(0.0013)\end{array}$ \\
\hline Female & $\begin{array}{c}-0.0583 \\
(0.0712)\end{array}$ & $\begin{array}{c}-0.3191 * * * \\
(0.0749)\end{array}$ & $\begin{array}{c}-0.2895^{* *} \\
(0.1377)\end{array}$ \\
\hline Age & $\begin{array}{c}-0.0006 \\
(0.0027)\end{array}$ & $\begin{array}{c}-0.0060 * * \\
(0.0030)\end{array}$ & $\begin{array}{c}-0.0029 \\
(0.0050)\end{array}$ \\
\hline Low income & $\begin{array}{c}-0.0406 \\
(0.0676)\end{array}$ & $\begin{array}{c}0.0218 \\
(0.0763)\end{array}$ & $\begin{array}{c}-0.1095 \\
(0.1344)\end{array}$ \\
\hline High income & $\begin{array}{c}0.0021 \\
(0.0703)\end{array}$ & $\begin{array}{c}0.0693 \\
(0.0824)\end{array}$ & $\begin{array}{c}-0.1217 \\
(0.1354)\end{array}$ \\
\hline Untold income & $\begin{array}{c}-0.0804 \\
(0.0765)\end{array}$ & $\begin{array}{c}0.0422 \\
(0.0902)\end{array}$ & $\begin{array}{c}-0.1211 \\
(0.1444)\end{array}$ \\
\hline Constant & $\begin{array}{l}1.5046^{* * * *} \\
(0.2738)\end{array}$ & $\begin{array}{l}2.0682^{* * *} \\
(0.2868)\end{array}$ & $\begin{array}{l}1.8998 * * * \\
(0.5004)\end{array}$ \\
\hline Observations & 679 & 1,991 & 679 \\
\hline Adjusted- $R^{2}$ & -0.0066 & 0.2110 & 0.2234 \\
\hline
\end{tabular}

\section{Are SRIs Related to Charitable Donations?}

In this section, we examine whether SRI substitute for other expressions of social concern, such as charitable giving. Graff Zivin and Small (2005) theorize that individuals may perceive SRI as a more efficient way of achieving their social goals than direct donations to charity. In their model, donations and corporate philanthropy are perfect substitutes.

regard to this correlation, in Table VI we run additional regressions for Signaling without the Female dummy in specification (2) and without the Investment knowledge variable in specification (3). The results, reported in Table IAI of the Internet Appendix, are robust to these variations. 
Table VII

\section{Relation between Socially Responsible Investments and Charitable Giving}

The table presents an OLS regression in which the dependent variable Log donations is the logarithm of the self-reported average yearly donation by the investor. For definitions of the variables, see Tables III and A.3. Robust standard errors are reported in parentheses. *, **, and *** indicate significance at the $10 \%, 5 \%$, and $1 \%$ level, respectively.

\begin{tabular}{|c|c|}
\hline & Log Donations \\
\hline SRI equity & $\begin{array}{l}0.4100 * * \\
(0.1765)\end{array}$ \\
\hline \multicolumn{2}{|l|}{ Portfolio characteristics } \\
\hline Average holding period & $\begin{array}{c}-0.0006 \\
(0.0046)\end{array}$ \\
\hline Log total portfolio value & $\begin{array}{c}0.0604 \\
(0.0473)\end{array}$ \\
\hline Log number of transactions & $\begin{array}{c}-0.0148 \\
(0.0498)\end{array}$ \\
\hline \multicolumn{2}{|l|}{ Individual characteristics } \\
\hline Investment knowledge & $\begin{array}{c}0.0271 \\
(0.0502)\end{array}$ \\
\hline University degree & $\begin{array}{c}0.0692 \\
(0.1354)\end{array}$ \\
\hline Risk preferences & $\begin{array}{r}-0.0016 \\
(0.0017)\end{array}$ \\
\hline Female & $\begin{array}{c}0.0757 \\
(0.1748)\end{array}$ \\
\hline Age & $\begin{array}{l}0.0305^{* * *} \\
(0.0068)\end{array}$ \\
\hline Low income & $\begin{array}{c}-0.2878^{*} \\
(0.1602)\end{array}$ \\
\hline High income & $\begin{array}{c}0.1670 \\
(0.1675)\end{array}$ \\
\hline Untold income & $\begin{array}{r}-0.3072 \\
(0.2454)\end{array}$ \\
\hline Constant & $\begin{array}{l}3.6367^{* * * *} \\
(0.6045)\end{array}$ \\
\hline Observations & 519 \\
\hline$R^{2}$ & 0.0809 \\
\hline
\end{tabular}

If SRI substitute for donations, ceteris paribus we would expect a negative relation between the likelihood of holding an SRI fund and the amount donated to charity. We test this hypothesis in Table VII using OLS. Although we cannot address causal effects with our data, our results can provide interesting evidence on the correlation between charity donations and SRI.

We define the dependent variable Log donations as the logarithm of the selfreported average euro amount that the investor donates to charity per year. The independent variable of main interest is SRI equity, which takes the value of one if an investor holds at least one SRI equity fund and zero otherwise. An eventual positive correlation between SRI and donations could be due to income 
and wealth effects. To control for this possibility, we include investors' portfolio value and self-reported income as explanatory variables. We also control for portfolio and individual characteristics included in the analyses above.

The results reported in Table VII show that donations are significantly positively related to holding an SRI equity fund ( $p=0.021)$. Specifically, an investor who holds an SRI equity fund donates $41 \%$ more to charity. We therefore reject the hypothesis that SRI and charity donations are substitutes.

\section{Discussion and Conclusion}

In this paper, we investigate why individuals hold socially responsible equity funds. We find that investors' intrinsic social preferences and, to a lesser extent, social signaling are major factors determining the likelihood of holding SRI equity funds. Financial motivations also play a role in SRI decisions. Investors who expect SRI equity funds to underperform relative to conventional equity funds are less likely to invest in a socially responsible manner. We also find that most socially responsible investors expect SRI funds to earn lower returns than conventional funds, to achieve worse Sharpe ratios, and to pay higher fees. The latter findings suggest that on average investors with a strong social motivation are willing to forgo financial returns in order to invest in accordance with their social preferences.

Our results have important implications for asset prices. In particular, because SRI are growing quickly in volume (EUROSIF (2014), SIF (2014)), our results on the effect of social preferences on SRI suggest that social preferences as well as social reputation motives may influence asset prices to a greater extent as the proportion of socially responsible investors in the market continues to grow.

We note that our sample is based on Dutch investors. This raises the question of the extent to which our findings generalize to other countries. According to EUROSIF (2014) and SIF (2014), the total assets under management in SRI are about 1.2 trillion euro in the Netherlands and 4.9 trillion euro in the United States. Thus, the amount invested in SRI is relatively large for a country the size of the Netherlands. To determine whether this is because the Dutch are more proenvironmental or prosocial than investors in the United States or other countries, we looked at several measures available in the literature.

According to data from the World Values Survey (World Values Survey Association (2016)), Dutch attitudes toward the environment are not particularly distinct. For instance, $45.2 \%$ of the Dutch agree that protecting the environment should have priority even if this means slower economic growth, which is on par with the $38.2 \%$ for the United States and 55.0\% for Germany. A similar result obtains when individuals are asked to indicate how strongly they identify with the statement "Looking after the environment is important to me; to care for nature and save life resources." In the Netherlands $62 \%$ of respondents agreed that this is "(Somewhat) Like me," compared to 66\% in the United States and $65 \%$ in Germany. Behavioral data paint a similar picture. According to ERNOP (2013), in 2013 households' per capita charity donations totaled 
116 euro in the Netherlands, which is higher than the 78 euro in Germany but lower than the 256 euros in the United Kingdom. ${ }^{24}$

These figures suggest that our results are not driven by different attitudes of the Dutch toward the environment and charitable giving and thus they may generalize to other countries. Whether our results do indeed carry through to different countries is ultimately an empirical question. Future research could investigate how the relation between social preferences and SRI is affected by variations in culture, economic development, religion, and other socioeconomic factors that may impact social preferences themselves as well as their effect on economic behavior in the field.

We find that financial motives play a relatively minor role in the decision to hold SRI equity. A caveat is in order here because we measure some important financial motives, like risk perception and expected return on SRI, using survey questions. As a result, these measures are likely more noisy than our measures of social preferences and risk preferences, which are based on an incentivized experiment. Future research could test the robustness of our results by developing incentive-compatible mechanisms for eliciting risk and return perceptions of SRI and conventional equity.

Our measure of social signaling also comes from survey data and thus is also prone to larger measurement error than our incentivized measures. Moreover, the proxy "talking about investment" is likely not a pure measure of social signaling. It is difficult to elicit social signaling in an incentive-compatible way, and it is also difficult to control for the way investors can signal information. These concerns may call for laboratory experiments on SRI where social preferences and social signaling could be more easily measured and signaling possibilities and content more tightly controlled.

We focus on preferences for investments in SRI equity funds. Recently, SRI has expanded to other asset classes such as hedge funds, impact investments, and fixed income. It would be interesting to explore the relative importance of social preferences, social signaling, and financial motives for these classes of SRI as well.

We deliberately use a broad definition of social preferences as a first approach to addressing the question of whether social preferences influence portfolio choice. Future research could test how specific models of other-regarding preferences are related to SRI. For instance, it would be interesting to learn whether socially responsible investors are more altruistic (Fehr and Fischbacher (2003)) than conventional investors or whether they receive more warm-glow from doing good (Andreoni (1990)).

In our study, we experimentally elicit social preferences using a trust game and relate it to field behavior regarding investment choices. Therefore, our paper contributes to the discussion about the stability of social preferences across different decision domains and the external relevance of lab experiments (Karlan (2005), List (2006), Levitt and List (2007), Benz and Meier

\footnotetext{
${ }^{24}$ Comparisons with other countries show a similar picture. For details we refer the reader to Tables IAII to IAV in the Internet Appendix.
} 
(2008), Falk and Heckman (2009), Baran, Sapienza, and Zingales (2010), Fehr and Leibbrandt (2011), Stoop, Noussair, and Van Soest (2012), Stoop (2014), Galizzi and Navarro-Martínez (2015)). Investors in our study were unaware that we matched their survey responses and experimental behavior to their (anonymized) trading records. This design mitigates the potential problem that socially responsible investors want to behave consistently prosocially in the experiment (for evidence on consistency, see Gneezy et al. (2012)) and minimizes experimenter demand effects. We find that social preferences measured in an experiment with relatively small stakes are strongly related to field behavior in the form of SRI worth thousands of euro. This result indicates that lab experiments on social preferences do have external relevance.

Initial submission: October 6, 2015; Accepted: January 21, 2017

Editors: Bruno Biais, Michael R. Roberts, and Kenneth J. Singleton

\section{Appendix}

Table A.1

\section{Survey Respondents and Overall Sample Characteristics}

This table compares the mean characteristics of all investors invited to participate in the survey and experiments to the mean characteristics of the respondents. Variable definitions are provided in Table A.3. Note that we purposefully oversampled socially responsible investors in the survey to increase the power of our analyses in which we compare socially responsible investors to conventional investors. The response rate for socially responsible investors is $12 \%$ and that for conventional investors is $8 \%$.

\begin{tabular}{lcc}
\hline & Invited Sample $(n=38,382)$ & Respondents $(n=3,254)$ \\
\hline Female & $24.7 \%$ & $20.6 \%$ \\
Age & 55.5 & 57.9 \\
Total portfolio value (euro) & 61,509 & 74,259 \\
$\%$ holding an SRI equity fund & $8.4 \%$ & $11.0 \%$ \\
\hline
\end{tabular}

Table A.2

Choice List in Risk Preferences Elicitation Experiment

\begin{tabular}{|c|c|c|c|}
\hline & Safe Payment & & Lottery \\
\hline 1) & $€ 0$ for sure & or & $50 \%$ chance of winning $€ 300$ and $50 \%$ chance of winning $€ 0$ \\
\hline 2) & $€ 10$ for sure & or & $50 \%$ chance of winning $€ 300$ and $50 \%$ chance of winning $€ 0$ \\
\hline 3) & $€ 20$ for sure & or & $50 \%$ chance of winning $€ 300$ and $50 \%$ chance of winning $€ 0$ \\
\hline 4) & $€ 30$ for sure & or & $50 \%$ chance of winning $€ 300$ and $50 \%$ chance of winning $€ 0$ \\
\hline 5) & $€ 40$ for sure & or & $50 \%$ chance of winning $€ 300$ and $50 \%$ chance of winning $€ 0$ \\
\hline 6) & $€ 50$ for sure & or & $50 \%$ chance of winning $€ 300$ and $50 \%$ chance of winning $€ 0$ \\
\hline 7) & $€ 60$ for sure & or & $50 \%$ chance of winning $€ 300$ and $50 \%$ chance of winning $€ 0$ \\
\hline 8) & $€ 70$ for sure & or & $50 \%$ chance of winning $€ 300$ and $50 \%$ chance of winning $€ 0$ \\
\hline
\end{tabular}


Table A.2-Continued

\begin{tabular}{|c|c|c|c|}
\hline & Safe Payment & & Lottery \\
\hline 9) & $€ 80$ for sure & or & $50 \%$ chance of winning $€ 300$ and $50 \%$ chance of winning $€ 0$ \\
\hline 10) & $€ 90$ for sure & or & $50 \%$ chance of winning $€ 300$ and $50 \%$ chance of winning $€ 0$ \\
\hline 11) & $€ 100$ for sure & or & $50 \%$ chance of winning $€ 300$ and $50 \%$ chance of winning $€ 0$ \\
\hline 12) & $€ 110$ for sure & or & $50 \%$ chance of winning $€ 300$ and $50 \%$ chance of winning $€ 0$ \\
\hline 13) & $€ 120$ for sure & or & $50 \%$ chance of winning $€ 300$ and $50 \%$ chance of winning $€ 0$ \\
\hline 14) & $€ 130$ for sure & or & $50 \%$ chance of winning $€ 300$ and $50 \%$ chance of winning $€ 0$ \\
\hline 15) & $€ 140$ for sure & or & $50 \%$ chance of winning $€ 300$ and $50 \%$ chance of winning $€ 0$ \\
\hline 16) & $€ 150$ for sure & or & $50 \%$ chance of winning $€ 300$ and $50 \%$ chance of winning $€ 0$ \\
\hline 17) & $€ 160$ for sure & or & $50 \%$ chance of winning $€ 300$ and $50 \%$ chance of winning $€ 0$ \\
\hline 18) & $€ 170$ for sure & or & $50 \%$ chance of winning $€ 300$ and $50 \%$ chance of winning $€ 0$ \\
\hline 19) & $€ 180$ for sure & or & $50 \%$ chance of winning $€ 300$ and $50 \%$ chance of winning $€ 0$ \\
\hline 20) & $€ 190$ for sure & or & $50 \%$ chance of winning $€ 300$ and $50 \%$ chance of winning $€ 0$ \\
\hline
\end{tabular}

Table A.3

Variable Definitions

\begin{tabular}{l}
\hline Variable \\
\hline Administrative \\
SRI equity fund
\end{tabular}

Socially responsible investor Percentage in SRI equity funds

Log total portfolio value

Log number of transactions

Average holding period

Mean portfolio returns

Volatility of portfolio returns

Sharpe ratio
Measure

Dummy variable equal to one if the investor holds an SRI equity fund in his or her portfolio in the month he or she participated in the survey and experiment.

An investor who holds at least one SRI equity fund.

The average amount the investor invested in SRI equity funds in the year after the survey and experiment, as a percentage of the total amount he or she invested in equity funds.

Logarithm of the investor's average euro amount invested at the provider in the year before the survey and experiment.

Logarithm of the number of transactions the investor made in the year before the survey and experiment. To account for extremes, this measure is trimmed by excluding the $1^{\text {st }}$ and the $99^{\text {th }}$ percentiles.

Average number of months the investor holds a mutual fund in the five years before the survey and experiment.

Average portfolio returns in the year before the investor participated in the survey and experiment (in \%). To account for extremes, this measure is trimmed by excluding the $1^{\text {st }}$ and the $99^{\text {th }}$ percentile.

Standard deviation of the yearly portfolio returns in the year before the investor participated in the experiment (in \%) using monthly return data.

Sharpe ratio of the portfolio performance in the year before the investor participated in the experiment. 
Table A.3-Continued

\begin{tabular}{ll}
\hline Variable & Measure \\
\hline
\end{tabular}

Survey

Expected returns on SRI

Perceived risk on $S R I$

Lower expected returns on SRI

Higher expected returns on SRI

Lower perceived risk on SRI

Higher perceived risk on SRI

Signaling

Strong signaling

Investment knowledge

Perceived social impact

University degree

Female

Age

Low income

Medium income

High income

Untold income

Log donations

Incentivized experiment Risk preferences
The investor's response to the statement "I expect that the returns of socially responsible equity funds compared to conventional equity funds are:

much lower

a bit lower

the same

a bit higher

much higher

I do not know."

(1 much lower, ..., 5 much higher)

The investor's response to the statement "Socially responsible equity funds are more risky than conventional equity funds." (1 fully disagree, ..., 7 fully agree)

Dummy variable equal to one if the investor believes that the returns on SRI equity funds are a bit or much lower than the returns on conventional equity funds.

Dummy variable equal to one if the investor believes that the returns on SRI equity funds are a bit or much higher than the returns on conventional equity funds.

Dummy variable equal to one if an investor disagrees with the statement that the risk on SRI equity funds is higher than the risk on conventional equity funds.

Dummy variable equal to one if an investor agrees with the statement that the risk on SRI equity funds is higher than the risk on conventional equity funds.

The investor's response to the statement "I often talk about investment with others." (1 fully disagree, . ., 7 fully agree).

Dummy variable equal to one if the investor's response to the statement "I often talk about investment with others" ( 1 fully disagree, .., 7 fully agree) is greater than or equal to the median.

The investor's response to the statement "My investment knowledge is good." (1 fully disagree, .., 7 fully agree).

Dummy variable equal to one if the investor's response to the statement "Socially responsible investment funds have a positive influence on society" ( 1 fully disagree, ., , 7 fully agree) is greater than or equal to the median.

Dummy variable equal to one if the investor reports having a university degree.

Dummy variable equal to one if the investor reports being a woman.

The investor's self-reported age.

Dummy variable equal to one if the investor's reported annual gross family income is below 60,000 euro.

Dummy variable equal to one if the investor's reported annual gross family income is between 60,000 euro and 100,000 euro.

Dummy variable equal to one if the investor's reported annual gross family income is above 100,000 euro.

Dummy variable equal to one if the investor does not disclose his or her income.

Logarithm of the average yearly amount that the investor reports donating to charity.

Risk-free money amount at which the investor switches from choosing the risky lottery to choosing the risk-free option in the risk preferences elicitation task. A higher amount indicates that the investor is more risk-tolerant. 
Table A.3-Continued

\begin{tabular}{|c|c|}
\hline Variable & Measure \\
\hline Intrinsic social preferences & $\begin{array}{l}\text { Social preferences are measured by the second mover's } \\
\text { behavior in the trust game. The second mover indicates how } \\
\text { much he or she wants to send back for each possible amount } \\
\text { that the first mover could send. To construct this variable, we } \\
\text { first calculate the return ratio for each possible first mover } \\
\text { transfer in the trust game. If the first mover sends } 5 \text { euro, } \\
\text { the amount the second mover returns is divided by } 5 \text {; if the } \\
\text { first mover sends } 10 \text { euro the amount the second mover } \\
\text { returns is divided by } 10 \text {; etc. We then calculate the average of } \\
\text { these ratios across the range of the } 5 \text { to } 50 \text { euro first mover } \\
\text { transfers. The measure varies from } 0 \text { to } 3 \text {. }\end{array}$ \\
\hline Strong social preferences & $\begin{array}{l}\text { Dummy variable that takes the value one if the investor has an } \\
\text { average return ratio in the trust game of } 2 \text { or higher. This } \\
\text { means splitting the amount of money in the experiment at } \\
\text { least equally. The variable takes the value of zero otherwise. }\end{array}$ \\
\hline Weak social preferences & $\begin{array}{l}\text { Dummy variable that takes the value of one if the investor has } \\
\text { an average return ratio in the trust game of less than } 2 \text {. This } \\
\text { means giving the other player less than half of the money in } \\
\text { the experiment. The variable takes the value of zero } \\
\text { otherwise. }\end{array}$ \\
\hline $\begin{array}{l}\text { Weak social preferences \& } \\
\text { strong signaling }\end{array}$ & $\begin{array}{l}\text { Dummy variable equal to one if the investor has both weak } \\
\text { social preferences and strong signaling and zero otherwise. }\end{array}$ \\
\hline
\end{tabular}

Table A.4

\section{Summary Statistics and Comparison of Investors with and without SRI Equity Funds}

This table presents summary statistics for investors with and without SRI equity funds. Variable definitions are provided in Table A.3. If not otherwise indicated in Table A.3, the statistics represent the portfolios of investors in the month in which they participated in the experiment and the survey. Standard deviations are in parentheses and $p$-values are from two-sided $t$-tests $\left({ }^{\mathrm{a}}\right)$ or $\boldsymbol{X}^{2}$ tests $\left({ }^{\mathrm{b}}\right)$. For highly skewed variables, we only report $p$-values of their logarithmic transformations. Differences in the number of observations stem from the fact that not all participants in the experiments answered all survey questions.

\begin{tabular}{|c|c|c|c|c|c|c|c|}
\hline & \multicolumn{3}{|c|}{ Socially Responsible Investors } & \multicolumn{3}{|c|}{ Conventional Investors } & \multirow[t]{3}{*}{$\Delta$} \\
\hline & \multicolumn{3}{|c|}{$(16.2 \%)$} & \multicolumn{3}{|c|}{$(83.8 \%)$} & \\
\hline & Mean & Median & $N$ & Mean & Median & $N$ & \\
\hline $\begin{array}{l}\text { Percentage in SRI } \\
\text { equity funds }\end{array}$ & $23.03 \%$ & $9.82 \%$ & 146 & - & - & - & - \\
\hline \multicolumn{8}{|l|}{ Social motives } \\
\hline $\begin{array}{l}\text { Mean intrinsic social } \\
\text { preferences }\end{array}$ & $\begin{array}{l}1.53 \\
(0.66)\end{array}$ & 1.79 & 146 & $\begin{array}{c}1.41 \\
(0.68)\end{array}$ & 1.51 & 756 & $0.052^{\mathrm{a}}$ \\
\hline Signaling & $\begin{array}{c}3.41 \\
(1.48)\end{array}$ & 3 & 146 & $\begin{array}{c}3.06 \\
(1.49)\end{array}$ & 3 & 756 & $0.009^{\mathrm{a}}$ \\
\hline
\end{tabular}


Table A.4-Continued

\begin{tabular}{|c|c|c|c|c|c|c|c|}
\hline & \multirow{2}{*}{\multicolumn{3}{|c|}{$\frac{\text { Socially Responsible Investors }}{(16.2 \%)}$}} & \multirow{2}{*}{\multicolumn{3}{|c|}{$\begin{array}{c}\text { Conventional Investors } \\
(83.8 \%)\end{array}$}} & \multirow[t]{3}{*}{$\Delta$} \\
\hline & & & & & & & \\
\hline & Mean & Median & $N$ & Mean & Median & $N$ & \\
\hline \multicolumn{8}{|l|}{ Financial motives } \\
\hline $\begin{array}{l}\text { Lower expected } \\
\text { returns on SRI }\end{array}$ & $48.89 \%$ & & 135 & $56.17 \%$ & & 673 & $0.121^{b}$ \\
\hline $\begin{array}{l}\text { Higher expected } \\
\text { returns on SRI }\end{array}$ & $17.04 \%$ & & 135 & $14.41 \%$ & & 673 & $0.434^{\mathrm{b}}$ \\
\hline $\begin{array}{l}\text { Lower perceived risk } \\
\text { on SRI }\end{array}$ & $39.86 \%$ & & 138 & $43.02 \%$ & & 716 & $0.491^{b}$ \\
\hline $\begin{array}{l}\text { Higher perceived } \\
\text { risk on SRI }\end{array}$ & $18.84 \%$ & & 138 & $16.62 \%$ & & 716 & $0.525^{\mathrm{b}}$ \\
\hline \multicolumn{8}{|l|}{$\begin{array}{l}\text { Portfolio } \\
\quad \text { characteristics }\end{array}$} \\
\hline $\begin{array}{l}\text { Average holding } \\
\text { period }\end{array}$ & $\begin{array}{c}32.3 \\
(14.2)\end{array}$ & 29.5 & 146 & $\begin{array}{c}32.1 \\
(17.0)\end{array}$ & 28 & 752 & $0.890^{\mathrm{a}}$ \\
\hline Total portfolio value & $\begin{array}{c}104,332 \\
(262,880)\end{array}$ & 53,005 & 146 & $\begin{array}{c}70,235 \\
(146,468)\end{array}$ & 35,845 & 752 & - \\
\hline $\begin{array}{l}\text { Log total portfolio } \\
\text { value }\end{array}$ & $\begin{array}{l}10.70 \\
(1.38)\end{array}$ & 10.86 & 146 & $\begin{array}{l}10.25 \\
(1.57)\end{array}$ & 10.49 & 752 & $0.002^{\mathrm{a}}$ \\
\hline $\begin{array}{l}\text { Number of } \\
\text { transactions }\end{array}$ & $\begin{array}{c}15.5 \\
(18.0)\end{array}$ & 8 & 138 & $\begin{array}{c}17.2 \\
(22.0)\end{array}$ & 8 & 605 & - \\
\hline $\begin{array}{l}\text { Log number of } \\
\text { transactions }\end{array}$ & $\begin{array}{c}2.14 \\
(1.14)\end{array}$ & 2.08 & 138 & $\begin{array}{c}2.04 \\
(1.34)\end{array}$ & 2.08 & 605 & $0.438^{\mathrm{a}}$ \\
\hline \multicolumn{8}{|l|}{ Donations } \\
\hline Donations (in euro) & $\begin{array}{c}1,074 \\
(1,300)\end{array}$ & 500 & 106 & $\begin{array}{c}845 \\
(1,355)\end{array}$ & 300 & 525 & - \\
\hline Log donations & $\begin{array}{c}6.2 \\
(1.4)\end{array}$ & 6.2 & 106 & $\begin{array}{c}5.8 \\
(1.4)\end{array}$ & 5.7 & 525 & $0.008^{\mathrm{a}}$ \\
\hline \multicolumn{8}{|l|}{$\begin{array}{l}\text { Individual } \\
\text { characteristics }\end{array}$} \\
\hline $\begin{array}{l}\text { Investment } \\
\text { knowledge }\end{array}$ & $\begin{array}{c}4.34 \\
(91.13)\end{array}$ & 4 & 146 & $\begin{array}{c}4.08 \\
(1.38)\end{array}$ & 4 & 756 & $0.029^{\mathrm{a}}$ \\
\hline University degree & $58.96 \%$ & & 134 & $46.67 \%$ & & 705 & $0.009^{b}$ \\
\hline Risk preferences & $\begin{array}{c}115.8 \\
(39.4)\end{array}$ & 110 & 146 & $\begin{array}{l}112.2 \\
(40.8)\end{array}$ & 110 & 756 & $0.340^{\mathrm{a}}$ \\
\hline Female & $12.33 \%$ & & 146 & $18.73 \%$ & & 753 & $0.064^{b}$ \\
\hline Age & $\begin{array}{c}55.45 \\
(11.39)\end{array}$ & 55 & 144 & $\begin{array}{c}56.83 \\
(10.83)\end{array}$ & 56 & 751 & $0.166^{\mathrm{a}}$ \\
\hline Low income & $28.36 \%$ & & 134 & $30.47 \%$ & & 699 & $0.625^{b}$ \\
\hline High income & $20.90 \%$ & & 134 & $20.46 \%$ & & 699 & $0.909^{b}$ \\
\hline Untold income & $17.16 \%$ & & 134 & $17.31 \%$ & & 699 & $0.967^{\mathrm{b}}$ \\
\hline
\end{tabular}


Table A.5

\section{Exclusion of Investors Who Believe SRI Is a Marketing Trick}

This table reports results of regressions equivalent to those in Table III (specifications (1) and (2)) and Table IV (specifications (3) and (4)). Here, we exclude subjects who rate the statement "I think that socially responsible investment funds are a marketing trick with the goal to sell more funds" (1 fully disagree, .., 7 fully agree) with a 4 or higher (10.6\%). Specifications (1) and (3) present marginal effects of probit regressions. The dependent variable is SRI equity, which takes the value of one if an investor holds an SRI equity fund in the month he or she participated in the experiment and survey and zero otherwise. Specifications (2) and (4) present coefficients of OLS regressions. The dependent variable is \% in SRI equity funds, which is equal to the investor's holdings in SRI equity funds as a share of his or her total investments in equity. In specifications (2) and (4) only investors with a share greater than zero are considered. For definitions of the other variables, see Table A.3. Robust standard errors are reported in parentheses. *,**, and *** indicate significance at $10 \%, 5 \%$, and $1 \%$ level, respectively.

\begin{tabular}{|c|c|c|c|c|}
\hline & $\begin{array}{c}\text { Probit } \\
\text { Has SRI Equity } \\
\text { (1) }\end{array}$ & $\begin{array}{c}\text { OLS } \\
\% \text { in SRI Equity } \\
(2)\end{array}$ & $\begin{array}{c}\text { Probit } \\
\text { Has SRI Equity } \\
\text { (3) }\end{array}$ & $\begin{array}{c}\text { OLS } \\
\text { \% in SRI Equity }\end{array}$ \\
\hline \multicolumn{5}{|l|}{ Social motives } \\
\hline Social preferences & $\begin{array}{l}0.0802^{* * *} \\
(0.0252)\end{array}$ & $\begin{array}{r}-0.0314 \\
(0.0492)\end{array}$ & & \\
\hline Signaling & $\begin{array}{l}0.0269 * * \\
(0.0112)\end{array}$ & $\begin{array}{r}-0.0168 \\
(0.0159)\end{array}$ & & \\
\hline Strong social preferences & & & $\begin{array}{l}0.1027^{* *} \\
(0.0459)\end{array}$ & $\begin{array}{r}-0.0881 \\
(0.0720)\end{array}$ \\
\hline $\begin{array}{l}\text { Weak social preferences } \\
\text { \& strong signaling }\end{array}$ & & & $\begin{array}{c}0.0578 \\
(0.0442)\end{array}$ & $\begin{array}{c}-0.1290 * * \\
(0.0637)\end{array}$ \\
\hline \multicolumn{5}{|l|}{ Financial motives } \\
\hline Sharpe ratio & $\begin{array}{c}0.0108 \\
(0.0213)\end{array}$ & $\begin{array}{c}0.0637 \\
(0.0546)\end{array}$ & $\begin{array}{c}0.0137 \\
(0.0209)\end{array}$ & $\begin{array}{c}0.0574 \\
(0.0559)\end{array}$ \\
\hline $\begin{array}{l}\text { Lower expected returns } \\
\text { on SRI }\end{array}$ & $\begin{array}{r}-0.0561 * \\
(0.0335)\end{array}$ & $\begin{array}{r}-0.0353 \\
(0.0411)\end{array}$ & $\begin{array}{r}-0.0545 \\
(0.0340)\end{array}$ & $\begin{array}{r}-0.0445 \\
(0.0412)\end{array}$ \\
\hline $\begin{array}{l}\text { Higher expected returns } \\
\text { on SRI }\end{array}$ & $\begin{array}{r}-0.0419 \\
(0.0375)\end{array}$ & $\begin{array}{r}-0.0103 \\
(0.0633)\end{array}$ & $\begin{array}{r}-0.0426 \\
(0.0381)\end{array}$ & $\begin{array}{r}-0.0215 \\
(0.0618)\end{array}$ \\
\hline $\begin{array}{l}\text { Lower perceived risk on } \\
\text { SRI }\end{array}$ & $\begin{array}{r}-0.0558 * \\
(0.0307)\end{array}$ & $\begin{array}{r}-0.0207 \\
(0.0451)\end{array}$ & $\begin{array}{r}-0.0488 \\
(0.0310)\end{array}$ & $\begin{array}{r}-0.0213 \\
(0.0472)\end{array}$ \\
\hline $\begin{array}{l}\text { Higher perceived risk on } \\
\text { SRI }\end{array}$ & $\begin{array}{c}0.0180 \\
(0.0473)\end{array}$ & $\begin{array}{c}0.0653 \\
(0.0711)\end{array}$ & $\begin{array}{c}0.0147 \\
(0.0478)\end{array}$ & $\begin{array}{l}0.0565 \\
(0.0670)\end{array}$ \\
\hline \multicolumn{5}{|l|}{ Portfolio characteristics } \\
\hline Average holding period & $\begin{array}{l}0.0024^{* * *} \\
(0.0011)\end{array}$ & $\begin{array}{c}-0.0007 \\
(0.0019)\end{array}$ & $\begin{array}{l}0.0023^{* *} \\
(0.0011)\end{array}$ & $\begin{array}{c}-0.0012 \\
(0.0018)\end{array}$ \\
\hline Log total portfolio value & $\begin{array}{l}0.0425^{* * * *} \\
(0.0137)\end{array}$ & $\begin{array}{l}-0.0559 * * * \\
(0.0202)\end{array}$ & $\begin{array}{l}0.0407 * * * \\
(0.0139)\end{array}$ & $\begin{array}{l}-0.0542^{* * * *} \\
(0.0194)\end{array}$ \\
\hline $\begin{array}{l}\text { Log number of } \\
\text { transactions }\end{array}$ & $\begin{array}{c}0.0227 * \\
(0.0119)\end{array}$ & $\begin{array}{c}0.0317 \\
(0.0241)\end{array}$ & $\begin{array}{c}0.0225^{*} \\
(0.0117)\end{array}$ & $\begin{array}{l}0.0230 \\
(0.0225)\end{array}$ \\
\hline \multicolumn{5}{|l|}{ Individual characteristics } \\
\hline Investment knowledge & $\begin{array}{c}0.0027 \\
(0.0119)\end{array}$ & $\begin{array}{c}-0.0428^{* *} \\
(0.0210)\end{array}$ & $\begin{array}{c}0.0089 \\
(0.0114)\end{array}$ & $\begin{array}{c}-0.0433^{* *} \\
(0.0205)\end{array}$ \\
\hline University degree & $\begin{array}{l}0.0742^{* *} \\
(0.0327)\end{array}$ & $\begin{array}{c}0.0625 \\
(0.0495)\end{array}$ & $\begin{array}{l}0.0699 * * \\
(0.0331)\end{array}$ & $\begin{array}{c}0.0523 \\
(0.0502)\end{array}$ \\
\hline Risk preferences & $\begin{array}{c}-0.0003 \\
(0.0004)\end{array}$ & $\begin{array}{l}0.0013 * * \\
(0.0006)\end{array}$ & $\begin{array}{c}-0.0002 \\
(0.0004)\end{array}$ & $\begin{array}{l}0.0011^{* *} \\
(0.0006)\end{array}$ \\
\hline
\end{tabular}


Table A.5-Continued

\begin{tabular}{|c|c|c|c|c|}
\hline & $\begin{array}{c}\text { Probit } \\
\text { Has SRI Equity } \\
\text { (1) }\end{array}$ & $\begin{array}{c}\text { OLS } \\
\text { \% in SRI Equity } \\
(2)\end{array}$ & $\begin{array}{c}\text { Probit } \\
\text { Has SRI Equity } \\
\text { (3) }\end{array}$ & $\begin{array}{c}\text { OLS } \\
\% \text { in SRI Equity } \\
(4)\end{array}$ \\
\hline Female & $\begin{array}{c}0.0082 \\
(0.0430)\end{array}$ & $\begin{array}{c}0.0039 \\
(0.0575)\end{array}$ & $\begin{array}{c}-0.0036 \\
(0.0414)\end{array}$ & $\begin{array}{c}-0.0004 \\
(0.0524)\end{array}$ \\
\hline Age & $\begin{array}{c}-0.0024 \\
(0.0015)\end{array}$ & $\begin{array}{c}0.0001 \\
(0.0022)\end{array}$ & $\begin{array}{r}-0.0026^{*} \\
(0.0015)\end{array}$ & $\begin{array}{c}-0.0002 \\
(0.0023)\end{array}$ \\
\hline Low income & $\begin{array}{c}0.0080 \\
(0.0379)\end{array}$ & $\begin{array}{c}0.0357 \\
(0.0617)\end{array}$ & $\begin{array}{c}0.0069 \\
(0.0384)\end{array}$ & $\begin{array}{c}0.0302 \\
(0.0617)\end{array}$ \\
\hline High income & $\begin{array}{c}-0.0466 \\
(0.0360)\end{array}$ & $\begin{array}{c}0.0448 \\
(0.0711)\end{array}$ & $\begin{array}{c}-0.0494 \\
(0.0364)\end{array}$ & $\begin{array}{c}0.0468 \\
(0.0711)\end{array}$ \\
\hline Untold income & $\begin{array}{c}-0.0180 \\
(0.0422)\end{array}$ & $\begin{array}{c}-0.0583 \\
(0.0482)\end{array}$ & $\begin{array}{c}-0.0199 \\
(0.0423)\end{array}$ & $\begin{array}{c}-0.0507 \\
(0.0452)\end{array}$ \\
\hline Constant & & $\begin{array}{l}0.8324^{* * *} \\
(0.2977)\end{array}$ & & $\begin{array}{l}0.8866^{* * *} \\
(0.2456)\end{array}$ \\
\hline $\begin{array}{l}\text { Observations } \\
R^{2}\end{array}$ & 566 & $\begin{array}{c}109 \\
0.2308\end{array}$ & 566 & $\begin{array}{c}109 \\
0.2512\end{array}$ \\
\hline
\end{tabular}

Table A.6

\section{Exclusion of Investors Who Failed at Least One Practice Question in Experiment}

This table reports results of regressions equivalent to those in Table III (specifications (1) and (2)) and Table IV (specifications (3) and (4)). Here, we exclude subjects who incorrectly answered at least one of the four practice questions three consecutive times (11.3\%). Specifications (1) and (3) present marginal effects of probit regressions. The dependent variable is SRI equity, which takes the value of one if an investor holds an SRI equity fund in the month he or she participated in the experiment and survey and zero otherwise. Specifications (2) and (4) present coefficients of OLS regressions. The dependent variable is \% in SRI equity funds, which is equal to the investor's holdings in SRI equity funds as a share of his or her total investments in equity. In specifications (2) and (4) only investors with a share greater than zero are considered. For definitions of the other variables, see Table A.3. Robust standard errors are reported in parentheses. *, **, and *** indicate significance at the $10 \%, 5 \%$, and $1 \%$ level, respectively.

\begin{tabular}{|c|c|c|c|c|}
\hline & $\begin{array}{c}\text { Probit } \\
\text { Has SRI Equity } \\
\text { (1) }\end{array}$ & $\begin{array}{c}\text { OLS } \\
\% \text { in SRI Equity } \\
(2)\end{array}$ & $\begin{array}{c}\text { Probit } \\
\text { Has SRI Equity } \\
(3)\end{array}$ & $\begin{array}{c}\text { OLS } \\
\% \text { in SRI Equity }\end{array}$ \\
\hline \multicolumn{5}{|l|}{ Social motives } \\
\hline Social preferences & $\begin{array}{l}0.0789 * * * \\
(0.0258)\end{array}$ & $\begin{array}{c}-0.0018 \\
(0.0459)\end{array}$ & & \\
\hline Signaling & $\begin{array}{l}0.0235^{* *} \\
(0.0118)\end{array}$ & $\begin{array}{r}-0.0234 \\
(0.0180)\end{array}$ & & \\
\hline Strong social preferences & & & $\begin{array}{l}0.1151^{* *} \\
(0.0465)\end{array}$ & $\begin{array}{c}-0.1236 \\
(0.0819)\end{array}$ \\
\hline $\begin{array}{l}\text { Weak social preferences } \\
\text { \& strong signaling }\end{array}$ & & & $\begin{array}{c}0.0670 \\
(0.0478)\end{array}$ & $\begin{array}{c}-0.2116^{* * *} \\
(0.0792)\end{array}$ \\
\hline
\end{tabular}


Table A.6-Continued

\begin{tabular}{|c|c|c|c|c|}
\hline & $\begin{array}{c}\text { Probit } \\
\text { Has SRI Equity } \\
\text { (1) }\end{array}$ & $\begin{array}{c}\text { OLS } \\
\% \text { in SRI Equity } \\
(2)\end{array}$ & $\begin{array}{c}\text { Probit } \\
\text { Has SRI Equity } \\
\text { (3) }\end{array}$ & $\begin{array}{c}\text { OLS } \\
\% \text { in SRI Equity } \\
(4)\end{array}$ \\
\hline \multicolumn{5}{|l|}{ Financial motives } \\
\hline Sharpe ratio & $\begin{array}{c}0.0097 \\
(0.0224)\end{array}$ & $\begin{array}{c}0.0680 \\
(0.0536)\end{array}$ & $\begin{array}{c}0.0138 \\
(0.0217)\end{array}$ & $\begin{array}{c}0.0550 \\
(0.0550)\end{array}$ \\
\hline $\begin{array}{l}\text { Lower expected returns } \\
\text { on SRI }\end{array}$ & $\begin{array}{r}-0.0504 \\
(0.0342)\end{array}$ & $\begin{array}{r}-0.0634 \\
(0.0516)\end{array}$ & $\begin{array}{c}-0.0471 \\
(0.0345)\end{array}$ & $\begin{array}{r}-0.0595 \\
(0.0458)\end{array}$ \\
\hline $\begin{array}{l}\text { Higher expected returns } \\
\text { on SRI }\end{array}$ & $\begin{array}{r}-0.0305 \\
(0.0414)\end{array}$ & $\begin{array}{r}-0.0170 \\
(0.0701)\end{array}$ & $\begin{array}{r}-0.0299 \\
(0.0420)\end{array}$ & $\begin{array}{r}-0.0141 \\
(0.0669)\end{array}$ \\
\hline $\begin{array}{l}\text { Lower perceived risk on } \\
\text { SRI }\end{array}$ & $\begin{array}{c}-0.0621^{*} \\
(0.0322)\end{array}$ & $\begin{array}{r}-0.0157 \\
(0.0526)\end{array}$ & $\begin{array}{c}-0.0574^{*} \\
(0.0325)\end{array}$ & $\begin{array}{r}-0.0247 \\
(0.0513)\end{array}$ \\
\hline $\begin{array}{l}\text { Higher perceived risk on } \\
\text { SRI }\end{array}$ & $\begin{array}{r}-0.0016 \\
(0.0471)\end{array}$ & $\begin{array}{c}0.0857 \\
(0.0773)\end{array}$ & $\begin{array}{r}-0.0079 \\
(0.0467)\end{array}$ & $\begin{array}{c}0.0864 \\
(0.0699)\end{array}$ \\
\hline \multicolumn{5}{|l|}{ Portfolio characteristics } \\
\hline Average holding period & $\begin{array}{l}0.0025^{* *} \\
(0.0011)\end{array}$ & $\begin{array}{c}-0.0004 \\
(0.0020)\end{array}$ & $\begin{array}{l}0.0025^{* *} \\
(0.0011)\end{array}$ & $\begin{array}{c}-0.0012 \\
(0.0019)\end{array}$ \\
\hline Log total portfolio value & $\begin{array}{l}0.0401^{* * *} \\
(0.0138)\end{array}$ & $\begin{array}{l}-0.0560 * * * \\
(0.0208)\end{array}$ & $\begin{array}{l}0.0380 * * * \\
(0.0139)\end{array}$ & $\begin{array}{l}-0.0567 * * * \\
(0.0199)\end{array}$ \\
\hline $\begin{array}{r}\text { Log number of } \\
\text { transactions }\end{array}$ & $\begin{array}{l}0.0340^{* * * *} \\
(0.0123)\end{array}$ & $\begin{array}{c}0.0211 \\
(0.0289)\end{array}$ & $\begin{array}{l}0.0342^{* * * *} \\
(0.0121)\end{array}$ & $\begin{array}{c}0.0098 \\
(0.0264)\end{array}$ \\
\hline \multicolumn{5}{|l|}{ Individual characteristics } \\
\hline Investment knowledge & $\begin{array}{c}0.0005 \\
(0.0127)\end{array}$ & $\begin{array}{c}-0.0414^{* *} \\
(0.0201)\end{array}$ & $\begin{array}{c}0.0050 \\
(0.0121)\end{array}$ & $\begin{array}{l}-0.0479 * * \\
(0.0186)\end{array}$ \\
\hline University degree & $\begin{array}{l}0.0676 * * \\
(0.0340)\end{array}$ & $\begin{array}{c}0.0588 \\
(0.0593)\end{array}$ & $\begin{array}{c}0.0623^{*} \\
(0.0344)\end{array}$ & $\begin{array}{c}0.0449 \\
(0.0564)\end{array}$ \\
\hline Risk preferences & $\begin{array}{c}-0.0001 \\
(0.0004)\end{array}$ & $\begin{array}{l}0.0018^{* * *} \\
(0.0007)\end{array}$ & $\begin{array}{c}-0.0001 \\
(0.0004)\end{array}$ & $\begin{array}{l}0.0017^{* * * *} \\
(0.0006)\end{array}$ \\
\hline Female & $\begin{array}{c}0.0142 \\
(0.0459)\end{array}$ & $\begin{array}{c}-0.0087 \\
(0.0622)\end{array}$ & $\begin{array}{c}0.0034 \\
(0.0443)\end{array}$ & $\begin{array}{c}-0.0189 \\
(0.0558)\end{array}$ \\
\hline Age & $\begin{array}{c}-0.0021 \\
(0.0015)\end{array}$ & $\begin{array}{c}0.0020 \\
(0.0022)\end{array}$ & $\begin{array}{c}-0.0024 \\
(0.0016)\end{array}$ & $\begin{array}{c}0.0021 \\
(0.0023)\end{array}$ \\
\hline Low income & $\begin{array}{c}0.0422 \\
(0.0431)\end{array}$ & $\begin{array}{c}0.0346 \\
(0.0626)\end{array}$ & $\begin{array}{c}0.0410 \\
(0.0435)\end{array}$ & $\begin{array}{c}0.0210 \\
(0.0624)\end{array}$ \\
\hline High income & $\begin{array}{r}-0.0287 \\
(0.0410)\end{array}$ & $\begin{array}{c}0.0043 \\
(0.0652)\end{array}$ & $\begin{array}{c}-0.0301 \\
(0.0413)\end{array}$ & $\begin{array}{c}0.0097 \\
(0.0635)\end{array}$ \\
\hline Untold income & $\begin{array}{c}-0.0029 \\
(0.0461)\end{array}$ & $\begin{array}{c}0.0112 \\
(0.0674)\end{array}$ & $\begin{array}{c}-0.0049 \\
(0.0454)\end{array}$ & $\begin{array}{c}0.0304 \\
(0.0622)\end{array}$ \\
\hline Constant & & $\begin{array}{l}0.6463^{* *} \\
(0.2956)\end{array}$ & & $\begin{array}{l}0.8127^{* * * *} \\
(0.2632)\end{array}$ \\
\hline $\begin{array}{l}\text { Observations } \\
R^{2}\end{array}$ & 555 & $\begin{array}{c}112 \\
0.2250\end{array}$ & 555 & $\begin{array}{c}112 \\
0.2950\end{array}$ \\
\hline
\end{tabular}




\section{Table A.7}

\section{Exclusion of Investors Who Expect Higher Returns on SRI and Perceive Lower Risk, but Do Not Hold SRI Funds}

This table reports results of regressions equivalent to those in Table III (specifications (1) and (2)) and Table IV (specifications (3) and (4)). Here, we exclude subjects who do not invest in SRI equity funds but expect such funds to yield higher returns at lower risk compared to normal equity funds (6.5\%). Specifications (1) and (3) present marginal effects of probit regressions. The dependent variable is SRI equity, which takes the value of one if an investor holds an SRI equity fund in the month he or she participated in the experiment and survey and zero otherwise. Specifications (2) and (4) present coefficients of OLS regressions. The dependent variable is \% in SRI equity funds, which is equal to the investor's holdings in SRI equity funds as a share of his or her total investments in equity. In specifications (2) and (4) only investors with a share greater than zero are considered. For definitions of the other variables, see Table A.3. Robust standard errors are reported in parentheses. *, **, and *** indicate significance at the $10 \%, 5 \%$, and $1 \%$ level, respectively.

\begin{tabular}{cccc}
\hline Probit & OLS & Probit & OLS \\
Has SRI Equity & $\%$ in SRI Equity & Has SRI Equity & \% in SRI Equity \\
$(1)$ & $(2)$ & $(3)$ & $(4)$
\end{tabular}

Social motives

Social preferences

$\begin{array}{cc}0.0755^{* * *} & -0.0151 \\ (0.0253) & (0.0486) \\ 0.0272^{* *} & -0.0158 \\ (0.0116) & (0.0172)\end{array}$

Signaling

$(0.0116)$

$(0.0172)$

Strong social preferences

Weak social preferences \& strong signaling

$\begin{array}{cc}0.1192^{* *} & -0.1061 \\ (0.0469) & (0.0824) \\ 0.0747 & -0.1575^{* *} \\ (0.0457) & (0.0788)\end{array}$

Financial motives

Sharpe ratio

$-0.0002$

0.0598

0.0026

0.0522

$(0.0223)$

(0.0536)

$(0.0233)$

$(0.0550)$

Lower expected returns

$-0.0619 *$

$-0.0776$

$-0.0589 *$

$-0.0748$ on SRI

(0.0342)

$(0.0488)$

$(0.0345)$

(0.0456)

Higher expected returns

0.0687

$-0.0079$

0.0648

$-0.0082$ on SRI

(0.0638)

(0.0699)

$(0.0632)$

(0.0678)

Lower perceived risk on SRI

Higher perceived risk on

$-0.0089$

$-0.0039$

$(0.0333)$

$(0.0513)$

$-0.0042$

$(0.0335)$

$-0.0102$

0.0043

0.0630

0.0009

(0.0512)

(0.0462)

(0.0727)

0.0584

(0.0465)

(0.0657)

Portfolio characteristics

Average holding period

Log total portfolio value

Log number of transactions

$\begin{array}{cccc}0.0024^{* *} & -0.0016 & 0.0025^{* *} & -0.0022 \\ (0.0011) & (0.0019) & (0.0011) & (0.0019) \\ 0.0430^{* * *} & -0.0566^{* * *} & 0.0407^{* * *} & -0.0560^{* * *} \\ (0.0136) & (0.0196) & (0.0137) & (0.0190) \\ 0.0262^{* *} & 0.0175 & 0.0268^{* *} & 0.0101 \\ (0.0124) & (0.0267) & (0.0122) & (0.0250) \\ & & & \\ 0.0022 & -0.0303 & 0.0081 & -0.0323^{*} \\ (0.0130) & (0.0190) & (0.0125) & (0.0183) \\ 0.0546 & 0.0503 & 0.0499 & 0.0440 \\ (0.0333) & (0.0545) & (0.0336) & (0.0537)\end{array}$

Individual characteristics Investment knowledge

University degree

$$
\text { (0.0333) }
$$$$
0.0503
$$

(0.0336)

0.0440 
Table A.7-Continued

\begin{tabular}{lcccc}
\hline & Probit & OLS & Probit & OLS \\
& Has SR Equity & in SRI Equity & Has SRI Equity \\
& $(1)$ & $(2)$ & $(3)$ & $\begin{array}{c}\text { \% in SRI Equity } \\
(4)\end{array}$ \\
\hline Risk preferences & -0.0001 & $0.0016^{* *}$ & -0.0001 & $0.0015^{* * *}$ \\
Female & $(0.0004)$ & $(0.0006)$ & $(0.0004)$ & $(0.0006)$ \\
& 0.0078 & -0.0247 & -0.0018 & -0.0270 \\
Age & $(0.0447)$ & $(0.0591)$ & $(0.0434)$ & $(0.0540)$ \\
Low income & -0.0021 & 0.0016 & -0.0024 & 0.0015 \\
& $(0.0015)$ & $(0.0023)$ & $(0.0015)$ & $(0.0023)$ \\
High income & 0.0168 & 0.0183 & 0.0150 & 0.0111 \\
& $(0.0401)$ & $(0.0607)$ & $(0.0403)$ & $(0.0597)$ \\
Untold income & -0.0200 & 0.0388 & -0.0261 & 0.0440 \\
Constant & $(0.0423)$ & $(0.0650)$ & $(0.0418)$ & $(0.0647)$ \\
Observations & -0.0100 & -0.0091 & -0.0136 & -0.0014 \\
$R^{2}$ & $(0.0442)$ & $(0.0667)$ & $(0.0436)$ & $(0.0635)$ \\
& & $0.7253^{* *}$ & & $0.8225^{* * *}$ \\
& & $(0.2927)$ & & $(0.2574)$ \\
& 582 & 119 & 582 & 119 \\
& & 0.1910 & & 0.2317 \\
\hline
\end{tabular}

\section{Table A.8}

\section{Inclusion of the Full Set of Signaling Dummies}

This table reports results of regressions similar to those in Table III but with the signaling variable fully dummied out. Specification (1) presents marginal effects of a probit regression. The dependent variable is SRI equity, which takes the value of one if the investor holds an SRI equity fund in the month he or she participated in the experiment and survey and zero otherwise. Specification (2) presents coefficients of an OLS regression. The dependent variable is \% in SRI equity funds, which is equal to the investor's holdings in SRI equity funds as a share of his or her total investments in equity. In specification (2) only investors with a share greater than zero are considered. Social signaling dummies: dummies for the extent to which the investor agrees with the statement "I often talk about investment with others" (1 fully disagree (base category), .. , 7 fully agree). All other variables are the same as in Table III. For definitions of these variables, see Table A.3. Robust standard errors are reported in parentheses. *, **, and *** indicate significance at the 10\%, 5\%, and $1 \%$ level, respectively.

\section{Probit}

Has SRI Equity

(1)
OLS

$\%$ in SRI Equity

(2)

\begin{tabular}{lcc}
\hline Social motives & & \\
Social preferences & $0.0708^{* * * *}$ & -0.0290 \\
& $(0.0234)$ & $(0.0467)$ \\
Social signaling dummy $=2$ & $0.1608^{* *}$ & 0.0617 \\
& $(0.0681)$ & $(0.1160)$ \\
Social signaling dummy $=3$ & $0.1630^{* *}$ & -0.0627 \\
& $(0.0796)$ & $(0.1185)$ \\
Social signaling dummy $=4$ & $0.1575^{* *}$ & 0.0587 \\
& $(0.0791)$ & $(0.1158)$ \\
\hline
\end{tabular}


Table A.8-Continued

\begin{tabular}{|c|c|c|}
\hline & $\begin{array}{c}\text { Probit } \\
\text { Has SRI Equity } \\
\text { (1) }\end{array}$ & $\begin{array}{c}\text { OLS } \\
\% \text { in SRI Equity } \\
\text { (2) }\end{array}$ \\
\hline Social signaling dummy $=5$ & $\begin{array}{l}0.2011 * * \\
(0.0912)\end{array}$ & $\begin{array}{c}-0.0323 \\
(0.1287)\end{array}$ \\
\hline Social signaling dummy $=6$ & $\begin{array}{r}0.2435^{*} \\
(0.1337)\end{array}$ & $\begin{array}{c}-0.0613 \\
(0.1376)\end{array}$ \\
\hline Social signaling dummy $=7$ & $\begin{array}{l}0.5851^{* *} \\
(0.2538)\end{array}$ & $\begin{array}{r}-0.0890 \\
(0.1352)\end{array}$ \\
\hline \multicolumn{3}{|l|}{ Financial motives } \\
\hline Sharpe ratio & $\begin{array}{c}-0.0028 \\
(0.0217)\end{array}$ & $\begin{array}{c}0.0546 \\
(0.0567)\end{array}$ \\
\hline Lower expected returns on SRI & $\begin{array}{c}-0.0588^{*} \\
(0.0318)\end{array}$ & $\begin{array}{c}-0.0871^{*} \\
(0.0493)\end{array}$ \\
\hline Higher expected returns on SRI & $\begin{array}{c}-0.0459 \\
(0.0357)\end{array}$ & $\begin{array}{c}-0.0378 \\
(0.0656)\end{array}$ \\
\hline Lower perceived risk on SRI & $\begin{array}{c}-0.0427 \\
(0.0299)\end{array}$ & $\begin{array}{l}-0.0146 \\
(0.0527)\end{array}$ \\
\hline Higher perceived risk on SRI & $\begin{array}{c}0.0116 \\
(0.0440)\end{array}$ & $\begin{array}{c}0.0758 \\
(0.0737)\end{array}$ \\
\hline \multicolumn{3}{|l|}{ Portfolio characteristics } \\
\hline Average holding period & $\begin{array}{l}0.0023^{* *} \\
(0.0010)\end{array}$ & $\begin{array}{c}-0.0021 \\
(0.0020)\end{array}$ \\
\hline Log total portfolio value & $\begin{array}{l}0.0374^{* * * *} \\
(0.0123)\end{array}$ & $\begin{array}{l}-0.0643^{* * *} \\
(0.0197)\end{array}$ \\
\hline Log number of transactions & $\begin{array}{l}0.0258^{* *} \\
(0.0114)\end{array}$ & $\begin{array}{c}0.0165 \\
(0.0258)\end{array}$ \\
\hline \multicolumn{3}{|l|}{ Individual characteristics } \\
\hline Investment knowledge & $\begin{array}{c}-0.0036 \\
(0.0119)\end{array}$ & $\begin{array}{r}-0.0363^{*} \\
(0.0201)\end{array}$ \\
\hline University degree & $\begin{array}{c}0.0585^{*} \\
(0.0312)\end{array}$ & $\begin{array}{c}0.0538 \\
(0.0536)\end{array}$ \\
\hline Risk preferences & $\begin{array}{c}-0.0001 \\
(0.0004)\end{array}$ & $\begin{array}{l}0.0015^{* *} \\
(0.0006)\end{array}$ \\
\hline Female & $\begin{array}{c}0.0031 \\
(0.0412)\end{array}$ & $\begin{array}{c}-0.0267 \\
(0.0578)\end{array}$ \\
\hline Age & $\begin{array}{r}-0.0025^{*} \\
(0.0014)\end{array}$ & $\begin{array}{c}0.0011 \\
(0.0021)\end{array}$ \\
\hline Low income & $\begin{array}{c}0.0285 \\
(0.0388)\end{array}$ & $\begin{array}{c}0.0205 \\
(0.0658)\end{array}$ \\
\hline High income & $\begin{array}{c}-0.0213 \\
(0.0383)\end{array}$ & $\begin{array}{c}0.0339 \\
(0.0654)\end{array}$ \\
\hline Untold income & $\begin{array}{c}-0.0032 \\
(0.0413)\end{array}$ & $\begin{array}{c}-0.0014 \\
(0.0702)\end{array}$ \\
\hline Constant & & $\begin{array}{l}0.8598 * * * \\
(0.3210)\end{array}$ \\
\hline $\begin{array}{l}\text { Observations } \\
R^{2}\end{array}$ & 625 & $\begin{array}{c}121 \\
0.2236\end{array}$ \\
\hline
\end{tabular}




\section{REFERENCES}

Andersson, Ola, Håkan J. Holm, Jean-Robert Tyran, and Erik Wengström, 2013, Risking other people's money: Experimental evidence on bonus schemes, competition and altruism, IFN Working papers 989, Research Institute of Industrial Economics, Stockholm.

Andreoni, Jim, 1990, Impure altruism and donations to public goods: A theory of warm-glow giving, The Economic Journal 100, 464-477.

Ariely, Dan, Anat Bracha, and Stephan Meier, 2009, Doing good or doing well? Image motivation and monetary incentives in behaving prosocially, American Economic Review 99, 544-555.

Baran, Nicole M., Paola Sapienza, and Luigi Zingales, 2010, Can we infer social preferences from the lab? Evidence from the trust game, No. w15654, National Bureau of Economic Research.

Baron, David P., 2007, Corporate social responsibility and social entrepreneurship, Journal of Economics \& Management Strategy 16, 683-717.

Bartling, Björn, Robert A. Weber, and Lan Yao, 2014, Do markets erode social responsibility? Quarterly Journal of Economics 130, 219-266.

Bauer, Rob, Kees Koedijk, and Rogér Otten, 2005, International evidence on ethical mutual fund performance and investment style, Journal of Banking \& Finance 29, 1751-1767.

Bauer, Rob, and Paul Smeets, 2015, Social identification and investment decisions, Journal of Economic Behavior and Organization 117, 121-134.

Bénabou, Roland, and Jean Tirole, 2006, Incentives and prosocial behavior, American Economic Review 96, 1652-1678.

Bénabou, Roland, and Jean Tirole, 2010, Individual and corporate social responsibility, Economica 77, 1-19.

Benz, Matthias, and Stephan Meier, 2008, Do people behave in experiments as in the field?Evidence from donations, Experimental Economics 11, 268-281.

Berg, Joyce, John Dickhaut, and Kevin McCabe, 1995, Trust, reciprocity, and social history, Games and Economic Behavior 10, 122-142.

Bollen, Nicolas P. B., 2007, Mutual fund attributes and investor behavior, Journal of Financial and Quantitative Analysis 42, 683-708.

Bolton, Gary E., and Axel Ockenfels, 2000, ERC: A theory of equity, reciprocity, and competition, American Economic Review 90, 166-193.

Borgers, Arian, Jeroen Derwall, Kees Koedijk, and Jenke Ter Horst, 2013, Stakeholder relations and stock returns: On errors in investors' expectations and learning, Journal of Empirical Finance 22, 159-175.

Camerer, Colin F., and Robin M. Hogarth, 1999, The effects of financial incentives in experiments: A review and capital-labor-production framework, Journal of Risk and Uncertainty 19, 7-42.

Cappelen, Alexander W., Trond Halvorsen, Erik Sørensen, and Bertil Tungodden, 2017, Facesaving or fair-minded: What motivates moral behavior? Journal of the European Economics Association 15, 540-557.

Cappelen, Alexander W., Knut Nygaard, Erik Ø. Sørensen, and Bertil Tungodden, 2015, Social preferences in the lab: A comparison of students and a representative population, Scandinavian Journal of Economics 117, 1306-1326.

Charness, Gary, and Matthew Rabin, 2002, Understanding social preferences with simple tests, Quarterly Journal of Economics 117, 817-869.

Cox, James C., 2004, How to identify trust and reciprocity, Games and Economic Behavior 46, $260-281$.

Cronqvist, Henrik, 2006, Advertising and portfolio choice, Working paper, available at SSRN: https://ssrn.com/abstract=920693.

De Bettignies, Jean-Etienne, and David T. Robinson, 2015, When is social responsibility socially desirable? NBER Working Paper No. w21364.

Derwall, Jeroen, Nadja Guenster, Rob Bauer, and Kees Koedijk, 2005, The eco-efficiency premium puzzle, Financial Analysts Journal 61, 51-63.

Di Giuli, Alberta, and Leonard Kostovetsky, 2014, Are red or blue companies more likely to go green? Politics and corporate social responsibility, Journal of Financial Economics 111, 158180. 
Dohmen, Thomas, Armin Falk, David Huffman, Uwe Sunde, Jürgen Schupp, and Gert G. Wagner, 2011, Individual risk attitudes: Measurement, determinants and behavioural consequences, Journal of the European Economics Association 9, 522-550.

Dorn, Daniel, and Gur Huberman, 2005, Talk and action: What individual investors say and what they do, Review of Finance 9, 437-481.

Dufwenberg, Martin, Paul Heidhues, Georg Kirchsteiger, Frank Riedel, and Joel Sobel, 2011, Other-regarding preferences in general equilibrium, Review of Economic Studies 78, 613-639.

Edmans, Alex, 2011, Does the stock market fully value intangibles? Employee satisfaction and equity prices, Journal of Financial Economics 101, 621-640.

Egas, Martijn, and Arno Riedl, 2008, The economics of altruistic punishment and the maintenance of cooperation, Proceedings of the Royal Society B: Biological Sciences 275, 871-878.

Ellingsen, Tore, and Magnus Johannesson, 2008, Pride and prejudice: The human side of incentive theory, American Economic Review 98, 990-1008.

ERNOP, 2013, Giving in Europe. The current state of research on giving by households, corporations, foundations and charity lotteries in Europe, ERNOP.EU Factsheet-v11072016-1, available at http://ernop.eu/wp-content/uploads/2016/07/.

EUROSIF, 2014, European SRI study 2014, available at http://www.eurosif.org.

Fabozzi, Frank J., K. C. Ma, and Becky J. Oliphant, 2008, Sin stock returns, Journal of Portfolio Management 35, 82-74.

Falk, Armin, and James J. Heckman, 2009, Lab experiments are a major source of knowledge in the social sciences, Science 326, 535-538.

Falk, Armin, Stephan Meier, and Christian Zehnder, 2013, Do lab experiments misrepresent social preferences? The case of self-selected student samples, Journal of the European Economic Association 11, 839-852.

Falk, Armin, and Christian Zehnder, 2013, A city-wide experiment on trust discrimination, Journal of Public Economics 100, 15-27.

Fama, Eugene F., and Kenneth R. French, 2007, Disagreement, tastes, and asset prices, Journal of Financial Economics 83, 667-689.

Fehr, Ernst, and Urs Fischbacher, 2003, The nature of human altruism, Nature 425, 785-791.

Fehr, Ernst, and Andreas Leibbrandt, 2011, A field study on cooperativeness and impatience in the tragedy of the commons, Journal of Public Economics 95, 1144-1155.

Fehr, Ernst, and John A. List, 2004, The hidden costs and returns of incentives-Trust and trustworthiness among CEOs, Journal of the European Economic Association 2, 743-771.

Fehr, Ernst, and Klaus M. Schmidt, 1999, A theory of fairness, competition and cooperation, Quarterly Journal of Economics 114, 817-868.

Fehrler, Sebastian, and Wojtek Przepiorka, 2013, Charitable giving as a signal of trustworthiness: Disentangling the signaling benefits of altruistic acts, Evolution and Human Behavior 34, $139-145$.

Galizzi, Matteo M., and Daniel Navarro-Martínez, 2015, On the external validity of socialpreference games: A systematic lab-field study, Working paper series no. 802, Barcelona Graduate School of Economics.

Glazer, Amihai, and Kai A. Konrad, 1996, A signaling explanation for charity, The American Economic Review 86, 1019-1028.

Gneezy, Ayelet, Alex Imas, Amber Brown, Leif D. Nelson, and Michael I. Norton, 2012, Paying to be nice: Consistency and costly prosocial behaviour, Management Science 58, 179-187.

Gollier, Christian, and Sébastien Pouget, 2014, The "washing machine": Investment strategies and corporate behavior with socially responsible investors, Working paper no. 14-457, Toulouse School of Economics.

Graff Zivin, Joshua, and Arthur Small, 2005, A Modigliani-Miller theory of altruistic corporate social responsibility, The B.E. Journal of Economic Analysis \& Policy 5. Retrieved from https://doi.org/10.1515/1538-0653.1369.

Graham, John R., Campbell R. Harvey, and Hai Huang, 2009, Investor competence, trading frequency, and home bias, Management Science 55, 1094-1106.

Guiso, Luigi, Paola Sapienza, and Luigi Zingales, 2013, The determinants of attitudes toward strategic default on mortgages, Journal of Finance 68, 1473-1515. 
Heinkel, Robert, Alan Kraus, and Josef Zechner, 2001, The effect of green investment on corporate behavior, Journal of Financial and Quantitative Analysis 36, 431-449.

Holt, Charles A., and Susan K. Laury, 2002, Risk aversion and incentive effects, American Economic Review 92, 1644-1655.

Hong, Harrison, and Marcin Kacperczyk, 2009, The price of sin: The effects of social norms on markets, Journal of Financial Economics 93, 15-36.

Hong, Harrison, and Leonard Kostovetsky, 2012, Red and blue investing: Values and finance, Journal of Financial Economics 103, 1-19.

Hood, Matthew, John R. Nofsinger, and Abhishek Varma, 2014, Conservation, discrimination, and salvation: Investors' social concerns in the stock market, Journal of Financial Services Research 45, 5-37.

Jain, Prem C., and Joanna Shuang Wu, 2000, Truth in mutual fund advertising: Evidence on future performance and fund flows, Journal of Finance 55, 937-958.

Karlan, Dean S., 2005, Using experimental economics to measure social capital and predict financial decisions, American Economic Review 95, 1688-1699.

Karpoff, Jonathan M., John R. Lott, Jr., and Eric W. Wehrly, 2005, The reputational penalties for environmental violations: Empirical evidence, Journal of Law and Economics 48, $653-675$.

Kempf, Alexander, and Peer Osthoff, 2007, The effect of socially responsible investing on portfolio performance, European Financial Management 13, 908-922.

Kreps, David M., Paul Milgrom, John Roberts, and Robert Wilson, 1982, Rational cooperation in the finitely repeated prisoners' dilemma, Journal of Economic Theory 27, 245-252.

Krüger, Philipp, 2015, Corporate goodness and shareholder wealth, Journal of Financial Economics $115,304-329$.

Levitt, Steven D., and John A. List, 2007, What do laboratory experiments measuring social preferences reveal about the real world? Journal of Economic Perspectives 21, 153-174.

List, John A., 2006, The behavioralist meets the market: Measuring social preferences and reputation effects in actual transactions, Journal of Political Economy 114, 1-37.

Nilsson, Jonas, 2008, Investment with a conscience: Examining the impact of pro-social attitudes and perceived financial performance on socially responsible investment behavior, Journal of Business Ethics 83, 307-325.

Oosterbeek, Hessel, Randolph Sloof, and Gijs Van De Kuilen, 2004, Cultural differences in ultimatum game experiments: Evidence from a meta-analysis, Experimental Economics 7, $171-188$.

Rabin, Matthew, 1993, Incorporating fairness into game theory and economics, American Economic Review 83, 1281-1302.

Renneboog, Luc, Jenke Ter Horst, and Chendi Zhang, 2011, Is ethical money financially smart? Nonfinancial attributes and money flows of socially responsible investment funds, Journal of Financial Intermediation 20, 562-588.

Selten, Reinhard, 1967, Die Strategiemethode zur Erforschung des eingeschränkt rationalen Verhaltens im Rahmen eines Oligopolexperiments, in Hans Sauermann, ed.: Beiträge zur experimentellen Wirtschaftsforschung (Mohr Siebeck, Tübingen, Germany).

Sobel, Joel, 2005, Interdependent preferences and reciprocity, Journal of Economic Literature 43, $392-436$.

Sobel, Joel, 2015, Do markets make people look selfish? Working paper, University of California San Diego.

Social Investment Forum (SIF), 2014, Report on socially responsible investing trends in the United States, Available at http://www.socialinvest.org.

Statman, Meir, 2004, What do investors want? Journal of Portfolio Management 30, 153-161.

Stoop, Jan, 2014, From the lab to the field: Envelopes, dictators and manners, Experimental Economics 17, 304-313.

Stoop, Jan, Charles N. Noussair, and Daan van Soest, 2012, From the lab to the field: Cooperation among fishermen, Journal of Political Economy 120, 1027-1056.

Van Rooij, Maarten, Annamaria Lusardi, and Rob Alessie, 2011, Financial literacy and stock market participation, Journal of Financial Economics 101, 449-472. 
World Values Survey Association (WVSA), 2016, World Values Survey Wave 6 2010-2014 Official Aggregate v.20150418. Aggregate File Producer: Asep/JDS, Madrid, Spain, available at http://www.worldvaluessurvey.org/WVSDocumentationWV6.jsp.

\section{Supporting Information}

Additional Supporting Information may be found in the online version of this article at the publisher's website:

Appendix S1: Internet Appendix. 
